\title{
Early and Middle Wisconsinan Environments of Eastern Beringia: Stratigraphic and Paleoecological Implications of the Old Crow Tephra
}

\author{
Les conditions environnementales au cours du Wisconsinien \\ inférieur et moyen en Béringie orientale : les conséquences de la \\ présence du tephra de Old Crow des points de vue \\ stratigraphique et paléoécologique \\ Die Umweltbedingungen in Ost-Beringia im frühen und \\ mittleren Wisconsin: stratigraphische und paläoökologische \\ Bedeutung des Tephra Vorkommens von Old Crow
}

\section{Charles E. Schweger et John V. Matthews}

Volume 39, numéro 3, 1985

URI : https://id.erudit.org/iderudit/032608ar

DOI : https://doi.org/10.7202/032608ar

Aller au sommaire du numéro

\section{Éditeur(s)}

Les Presses de l'Université de Montréal

ISSN

0705-7199 (imprimé)

1492-143X (numérique)

Découvrir la revue

Citer cet article

Schweger, C. E. \& Matthews, J. V. (1985). Early and Middle Wisconsinan Environments of Eastern Beringia: Stratigraphic and Paleoecological Implications of the Old Crow Tephra. Géographie physique et Quaternaire, 39(3), 275-290. https://doi.org/10.7202/032608ar

\section{Résumé de l'article}

Le tephra de Old Crow, se manifeste, entre autres, au trou de forage $\mathrm{V}$ à Imuruk Lake, en Alaska. Puisqu'il se situe après l'inversion magnétique de Blake, mais au-delà de la portée des datations au radio-carbone, la date approximative de son dépôt doit se situer entre 87000 et 105000 BP. La coupe KY-11 (Alaska), où l'on trouve le tephra dans une séquence lacustre, appuie cette hypothèse. Les registres de pollen fossile démontrent que le tephra de Old Crow s'est déposé dans le nord de la Béringie dans un milieu de toundra arbustive à bouleau, au cours d'une période froide. Plusieurs oscillations climatiques se sont succédé par la suite. Une longue période de climat aride froid (phase isotopique océanique 4) a précédé un épisode au climat plus chaud que maintenant et qui a commencé vers $60000 \mathrm{BP}$ environ. Durant cet épisode (que l'on nomme ici Koy-Yukon), l'émergence du pont terrestre de Bering a contribué à l'avènement d'un climat de type interglaciaire, qui a provoqué des changements de type biotique importants et la dégradation du pergélisol. Le tephra de Old Crow surmonte des dépôts de la glaciation de Mirror Creek, qui correspond aux glaciations qui se sont produites en Alaska et au Yukon au cours du Wisconsinien inférieur. Ces glaciations n'ont pu avoir lieu après la phase isotopique 5. Pendant la phase 4 , le climat était aussi froid que durant la phase 2 (Wisconsinien supérieur), mais il semble que cette période n'ait connu qu'un englacement limité. Il n'y a pas eu déglaciation pendant le Wisconsinien moyen (de 30000 à plus de 80000 BP), mais les fluctuations climatiques ont été nombreuses, dont l'épisode de Koy-Yukon. 


\section{EARLY AND MIDDLE WISCONSINAN ENVIRONMENTS OF EASTERN BERINGIA: STRATIGRAPHIC AND PALEOECOLOGICAL IMPLICATIONS OF THE OLD CROW TEPHRA}

Charles E. SCHWEGER and John V. MATTHEWS, Jr., Department of Anthropology, University of Alberta, Edmonton, Alberta T6G 2H4, and Geological Survey of Canada, Terrain Sciences Division, 601 Booth Street, Ottawa, Ontario K1A 0E8.

\begin{abstract}
The widespread Beringian Old Crow tephra occurs in Imuruk Lake (Alaska) core $\mathrm{V}$, above the Blake paleomagnetic event and below Radiocarbon dates, which provide an extrapolated tephra age between 87000 - 105000 BP. Exposure KY-11 (Alaska), where the tephra occurs in a dated lacustrine sequence, provides corroboration. Fossil pollen records show that O.C.T. was deposited across northern Beringia on birch-shrub tundra vegetation during an interval of colder climate. A series of climatic oscillations followed tephra deposition. A prolonged period of cold-arid climate (= marine isotope Stage 4) preceded an interval of warmer than present climate starting ca. 60000 BP (beginning Stage 3). During this interval, designated the Koy-Yukon thermal event, an exposed Bering land bridge promoted an interglacial type climate that led to significant biotic changes and permafrost degradation. O.C.T. occurs on drift of the Mirror Creek Glaciation which is equivalent to other presumed Early Wisconsinan glaciations in Alaska and Yukon. These glaciations could not have occurred later than marine Stage 5. Stage 4 was fully as cold as Stage 2 (Late Wisconsinan), yet seems not to have been a time of extensive glaciation. The Middle Wisconsinan, 30000 to more than 80000 $\mathrm{BP}$, was a nonglacial interval with several climate fluctuations, one of which, the KoyYukon thermal event, was warmer than at present.
\end{abstract}

RÉSUMÉ Les conditions environnementales au cours du Wisconsinien inférieur et moyen en Béringie orientale: les conséquences de la présence du tephra de Old Crow des points de vue stratigraphique et paléoécologique. Le tephra de Old Crow, se manifeste, entre autres, au trou de forage $\mathrm{V}$ à Imuruk Lake, en Alaska. Puisqu'il se situe après l'inversion magnétique de Blake, mais au-delà de la portée des datations au radiocarbone, la date approximative de son dépôt doit se situer entre 87000 et 105000 BP. La coupe KY-11 (Alaska), où l'on trouve le tephra dans une séquence lacustre, appuie cette hypothèse. Les registres de pollen fossile démontrent que le tephra de Old Crow s'est déposé dans le nord de la Béringie dans un milieu de toundra arbustive à bouleau, au cours d'une période froide. Plusieurs oscillations climatiques se sont succédé par la suite. Une longue période de climat aride froid (phase isotopique océanique 4) a précédé un épisode au climat plus chaud que maintenant et qui a commencé vers 60000 $\mathrm{BP}$ environ. Durant cet épisode (que I'on nomme ici Koy-Yukon), l'émergence du pont terrestre de Bering a contribué à l'avènement d'un climat de type interglaciaire, qui a provoqué des changements de type biotique importants et la dégradation du pergélisol. Le tephra de Old Crow surmonte des dépôts de la glaciation de Mirror Creek, qui correspond aux glaciations qui se sont produites en Alaska et au Yukon au cours du Wisconsinien inférieur. Ces glaciations n'ont pu avoir lieu après la phase isotopique 5 . Pendant la phase 4 , le climat était aussi froid que durant la phase 2 (Wisconsinien supérieur), mais il semble que cette période n'ait connu qu'un englacement limité. II n'y a pas eu deglaciation pendant le Wisconsinien moyen (de 30000 à plus de $80000 \mathrm{BP}$ ), mais les fluctuations climatiques ont été nombreuses, dont l'épisode de Koy-Yukon.
ZUSAMMENFASSUNG Die Umweltbedingungen in Ost-Beringia im frühen und mittleren Wisconsin: stratigraphische und paläoökologische Bedeutung des Tephra Vorkommens von Old Crow. Das weitverbreitete Tephra von Old Crow, Beringia, findet man auch am Bohrloch $V$ von Imuruk Lake (Alaska). Da es nach der Inversion von Blake und vor Radiokarbondatierungen liegt, muß die annähernde Zeit der Tephra-Ablagerung zwischen 87000 - 105000 v.u.Z. liegen. Der Schnitt KY-11 (Alaska), wo das Tephra in einer datierten Seesediment-Folge vorkommt, bestätigt diese Datierung. Belege von fossilem Pollen zeigen, daß Old Crow Tephra in NordBeringia in einem Milieu von Birken-BuschTundra während einer Periode kälteren Klimas abgelagert wurde. Auf die Tephra-Ablagerung folgte eine Serie von Klima-Schwankungen. Eine längere Periode von kalt-trockenem Klima (= marine isotopische Phase 4) ging einer Phase, die wärmer als das heutige Klima war und die etwa 60000 v.u.Z. begann (Beginn der Phase 3) voraus. Während dieser Zeitphase, die das thermische Koy-Yukon genannt wird, bewirkte eine ausgesetzte Bering Land-Brücke ein Klima des interglazialen Typus, welches $\mathrm{zu}$ bedeutenden biotischen Veränderungen und Permafrost Abtragungen führte. Old Crow Tephra findet sich über den Ablagerungen der Mirror Creek Vereisung, welche anderen mutmaßlich frühen Wisconsin Vereisungen in Alaska und Yukon entspricht. Diese Vereisungen können nicht später als in der marinen Phase 5 stattgefunden haben. Die Phase 4 war so kalt wie die Phase 2 (spätes Wisconsin), scheint jedoch keine Zeit extensiver Vereisung gewesen zu sein. Das mittlere Wisconsin, von 30000 bis mehr als 80000 v.u.Z., war eine nicht glaziale Zeitspanne mit gewissen Klima-Schwankungen, deren eine, das thermische Koy-Yukon, wärmer als die Jetztzeit war. 


\section{INTRODUCTION}

Distal tephras occur at a number of Quaternary exposures in Northwestern North America. Their study can provide many new insights on Quaternary stratigraphy, and when associated with fossils and organic deposits, they also make possible the reconstruction of coeval biotic patterns over lage areas (SCHWEGER and MATTHEWS, 1984). This paper deals with the paleoenvironmental implications of the Old Crow tephra of Yukon and Alaska (eastern Beringia) (NAESER et al., 1982; WESTGATE, 1982; WESTGATE et al., 1985). The unusually wide distribution of this tephra (Fig. 1) and its occurrence at a variety of sites with different depositional environments makes it a valuable datum for east Beringia, during a geological instant of Early Wisconsinan time, which is well beyond the range of radiocarbon dating (WESTGATE, 1982; WESTGATE et al., 1985).

The published Wisconsinan age stratigraphy and paleoenvironmental record for many of these sites are reviewed and in some cases reinterpreted. New fossil pollen data from Koyukuk River locality KY-11 and from Porcupine River locality Twelvemile Bluff are presented. Together, these data allow refinement of our understanding of the course of environmental change during the Wisconsinan (MATTHEWS and SCHWEGER, 1985). One outcome is the recognition of a climatic event, herein informally termed the "Koy-Yukon thermal event", which is recorded in sediments scattered across east Beringia and represents a period of remarkably strong climatic amelioration at the start of isotope Stage 3.

\section{FIELD AND LABORATORY METHODS}

Field work at locality KY-11, Koyukuk River, Alaska, was undertaken by one of the authors (C.E.S.) and T. D. Hamilton (U.S. Geological Survey, Anchorage). Sediment samples were collected at $10 \mathrm{~cm}$ intervals through the thickest portion of the lacustrine sequence. Fossil pollen extraction was accomplished using a $\mathrm{ZnBr}_{2}$ heavy liquid technique (SCHWEGER, 1976). Two hundred grain counts were made on each sample and these data were used to construct an abbreviated relative percent pollen diagram.

Porcupine River, Yukon, locality Twelvemile Bluff has been studied by both authors. Pollen samples from this site along with modern pollen surface samples were processed following a standard laboratory procedure (FAEGRI and IVERSEN, 1974). Unpublished pollen counts by S. Lichti-Federovich (Geological Survey of Canada, Ottawa) were made on samples collected by Owen Hughes (Geological Survey of Canada, Calgary). Their methods have been described elsewhere (LICHTI-FEDEROVICH, 1973, 1974). Macrofossils (seeds and insects) were recovered from selected Twelvemile Bluff sediment samples through wet sieving and flotation (MATTHEWS,

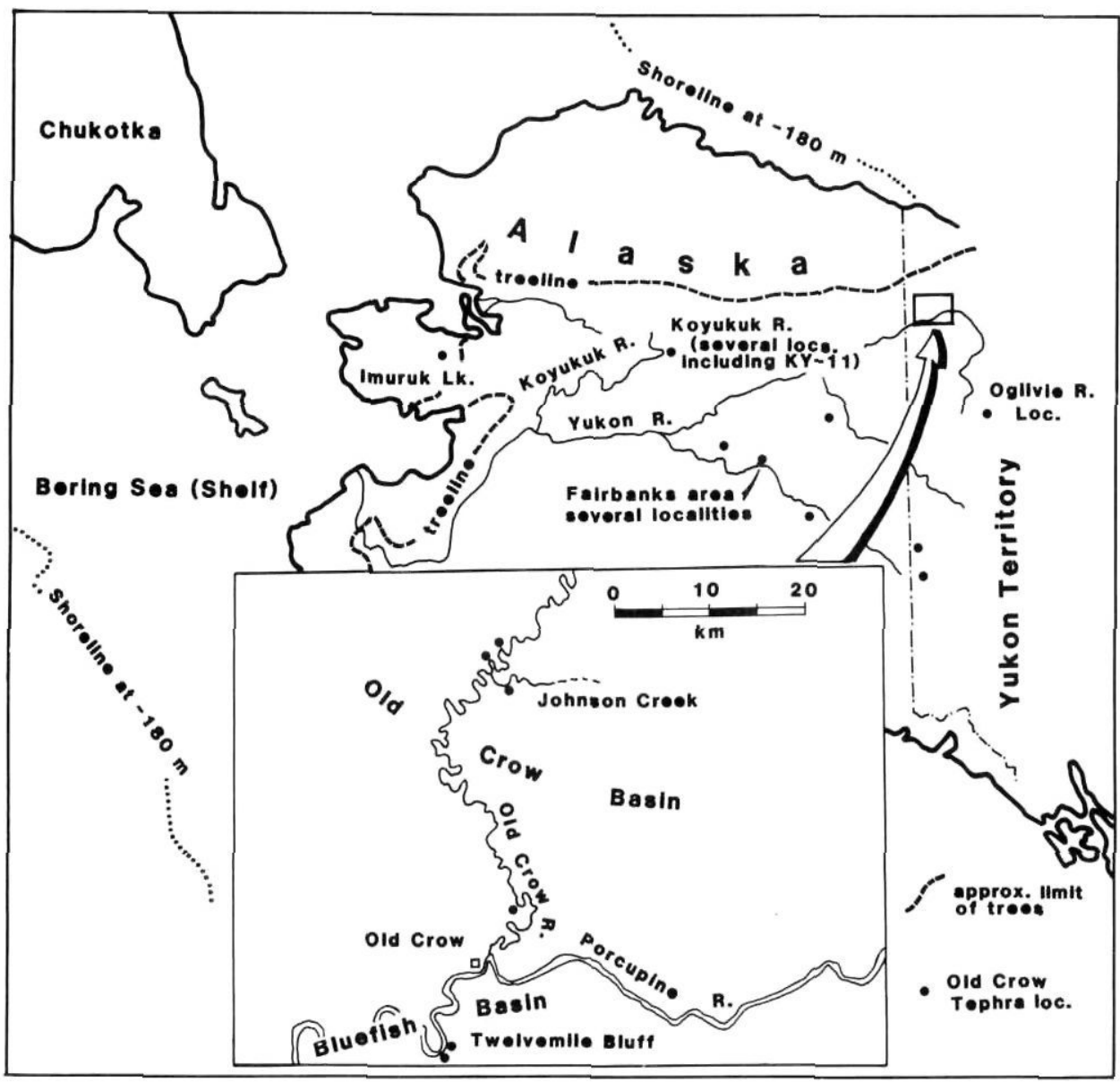

FIGURE 1. Distribution of Old Crow tephra in east Beringia (WESTGATE et al., 1985). Dashed line indicates approximate current position of treeline.

Répartition du tephra de Old Crow en Béringie orientale (WESTGATE et al., 1985). Les tirets montrent la limite approximative des arbres. 
1975). All macrofossil identifications were made by one of the authors (J.V.M.).

\section{OLD CROW TEPHRA LOCALITIES IN ALASKA-YUKON}

Old Crow tephra was first collected by O. L. Hughes (Geological Survey of Canada, Calgary) in 1968 during a study of the Twelvemile Bluff exposure (equivalent to Hughes' locality H 228$), 19 \mathrm{~km}$ down the Porcupine River from Old Crow, northern Yukon. The paleoecological data associated with the Old Crow tephra at this and four other sites are examined in the following section.

\section{IMURUK LAKE (ALASKA)}

COLINVAUX's benchmark study (1964) dealt with pollen from Imuruk Lake core I. Subsequent analyses of this core and other Imuruk Lake cores have refined the radiocarbon chronology (COLBAUGH, 1968) and resulted in discovery in core V (located approximately $3 \mathrm{~km} \mathrm{NW}$ of core I) of Old Crow tephra (SHACKLETON, 1982; WESTGATE, 1982) (Fig. 2). The tephra was deposited near the end of a long interval (pollen Zone $\mathrm{G}$ ) characterized by relatively high percentage values for Betula, Cyperaceae and Gramineae and (in the upper part) Artemisia (Fig. 2). A paleomagnetic excursion correlated with the Blake Event occurs within zone $\mathrm{G}_{2}$ (SCHACKLETON, 1982; WESTGATE et al., 1985).

Much lower values of Betula and somewhat higher frequencies of Cyperaceae and Gramineae characterize overlying Zone H. In Zone i, Picea, Alnus and Betula rise to maximum values, only to decline again higher in the sequence. Cyperaceae and Gramineae pollen frequencies dominate pollen Zone $\mathrm{J}$ at the top of this attenuated core. Core IV, collected $1 \mathrm{~m}$ from core $\mathrm{V}$, completes the record with zones $\mathrm{K}$ and $\mathrm{L}$, both characterized by high values of Betula and Picea, respectively (COLGAUGH, 1968). Surface pollen spectra from the area (cf. NELSON, 1979 for a compilation) contain significant quantities of alder (up to $20 \%$ ) and spruce, and high percentages of birch. Alders now grow $40 \mathrm{~km}$ to the north, the nearest spruce outliers are $25 \mathrm{~km}$ to the east (Fig. 1), and shrub birch is part of the local tundra vegetation (SHACKELTON, 1982).

Pollen core $V$ subzones $G_{2}, G_{4}$, and $H_{2}$ feature slightly higher values of Betula, Alnus, and Picea relative to adjacent subzones. SHACKLETON (1982) concludes that Zone G "suggests temperatures similar to the present" while Subzone $\mathrm{H}_{2}$ "seems to be a short period of climatic warming". Alnus is only a minor component throughout Zone $\mathrm{G}$, but its absence in Zone $\mathrm{G}_{3}$ (Fig. 2) may indicate somewhat colder and drier conditions than at present.

High values for Picea, Alnus, and Betula characterize Subzone $i_{1}$. The Picea frequencies of up to $44 \%$ are higher than in any other Imuruk zone including Holocene Zone L of cores I and IV. These values are also markedly higher than spruce pollen percentages in modern surface samples from the lake (COLINVAUX, 1964) and nearby coastal sites (MATTHEWS, 1974a; NELSON, 1979). Sphagnum maintains high values through Subzone $i_{1}$ in all of the Imuruk cores. According to
SHACKLETON (1982), "Zone $i_{1}$ suggests a period of time when the climate was at least as warm or possibly warmer than today." This zone was previously interpreted as representing the Sangamon Interglacial (COLINVAUX, 1964; COLBAUGH, 1968), a conclusion now invalidated by data from core $\mathrm{V}$ (see below).

\section{KOYUKUK REGION (ALASKA)}

The Koyukuk region is located in northcentral Alaska south of the Brooks Range (Fig. 1). The climate is continental. Valleys and lower slopes are forested with spruce, tree birch, alder, balsam poplar, and quaking aspen. Regional treeline occurs at elevations of $600-800 \mathrm{~m}$, approximately $400 \mathrm{~m}$ or more above the valleys where exposures containing the Old Crow tephra are found (HAMILTON, 1982; WESTGATE et al., 1983).

The Pleistocene stratigraphy of the region has recently been documented (HAMILTON, 1982). Several of the exposures contain the Old Crow tephra. At localities KY-10 and KY-12 (WESTGATE et al., 1983; Fig. 7) the discontinuous tephra layer was deposited along with loess on the former floodplain of the Koyukuk River. Wood from peat overlying the tephra at both localities has been dated at $59000+3200 /$ -5400 (QL-1284) and $52800 \pm 1300 \mathrm{BP}(\mathrm{QL}-1283)$, respectively. Koyukuk locality $11\left(66^{\circ} 32.5^{\prime} \mathrm{N} 152^{\circ} 05^{\prime} \mathrm{W}\right.$; herein designated $\mathrm{KY}-11$ ), a $55 \mathrm{~m}$ high bluff on the west side of the Koyukuk River, features the tephra near the base of a thick sequence of lacustrine silt overlain by a peat containing Picea wood dated $>56000$ BP (QL-1282). WESTGATE et al. (1983) conclude that the Old Crow tephra was deposited during the Itkillik Glaciation (HAMILTON, 1982) and was followed at approximately 50-60 000 BP by development of a forest bed representing interstadial conditions.

At KY-11 fifteen metres of organic silt and peat overlie 29 $m$ of glacial drift composed of sand, gravel, and till (WESTGATE et al., 1983; Fig. 7). This sequence represents the evolution of a small lake basin in which organic silt was first deposited, and followed, as the basin filled and became a fen or bog, by formation of a woody peat. The peat is 6-7 $\mathrm{m}$ above a well developed horizon of Old Crow tephra. Toward the upstream end of the exposure the underlying gravels rise and define one margin of the former lake and the tephra pinches out in near-shore sandy silts and gravels. The lacustrine sequence is thickest at a station (Table I) 75 m downstream from the pond margin.

The $0-80 \mathrm{~cm}$ interval is barren, but pollen is abundant and well preserved in every sample above $80 \mathrm{~cm}$. The arboreal (AP) component is dominated by Picea which initially rises to $14 \%$ then drops off to less than $5 \%$, until the $300 \mathrm{~cm}$ level, immediately above the Old Crow tephra, where Picea rises to $10 \%$. After falling again to less than $5 \%$, Picea reaches a third maximum of nearly $18 \%$ between $440 \mathrm{~cm}$ and $480 \mathrm{~cm}$. Above $520 \mathrm{~cm}$ Picea is rare until the spruce rich woody peat at the top of the section (uppermost sample, Fig. 3) where pollen values attain a maximum of $22 \%$. Alnus frequencies are low throughout. However, at $100 \mathrm{~cm}$ they reach $3 \%$ and at the top of the section they peak at $33 \%$. Betula percentages range from $8-12 \%$ over $80-100 \mathrm{~cm}$ and display a second 


\section{IMURUK LAKE CORE $V$}

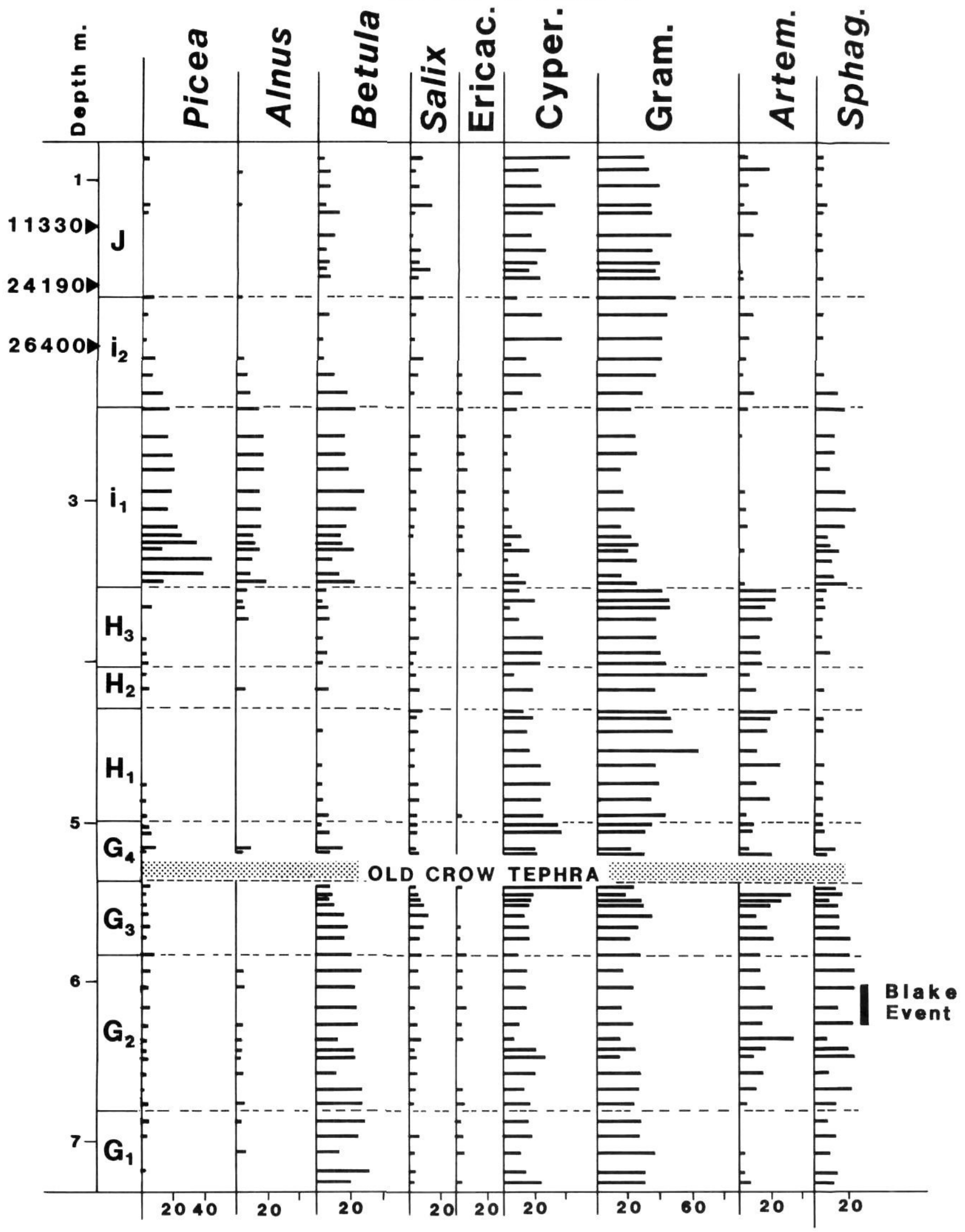

\% total pollen

FIGURE 2. Imuruk Lake core $V$ pollen diagram, modified from SHACKELTON (1982). Note that the diagram includes only the main pollen types but percentages represent percent of total pollen (excluding spores such as Sphagnum). Values less than $2 \%$ are not plotted. Eric.: Ericaceae; Cyper.: Cyperaceae; Gram: Gramineae; Artem. Artemisia; Sphag.: Sphagnum.
Diagramme pollinique du trou de forage $V$ de Imuruk Lake (modifie de SHACKELTON, 1982). Le diagramme ne comprend que les principaux types de pollen, mais les pourcentages comprennent l'ensemble du pollen (sauf les spores comme ceux de Sphagnum). Les taux inférieurs à $2 \%$ ne sont pas inclus. Eric.: Ericaceae; Cyper. Cyperaceae; Gram.: Gramineae; Artem.: Artemisia; Sphag. 
TABLE I

Sediment description of the Koyukuk Location KY-11 lacustrine sequence

$1460-1810 \mathrm{~cm}$ : Silts, disturbed and slumped slope material to top of section.

$1130-1400 \mathrm{~cm}$ : Silt, gray brown (5Y5/1), mottled red brown (10YR4/ 4). Non-bedded, compact. Organic content very fine grained, $2 \mathrm{~cm}$ thick peat bed at $1250 \mathrm{~cm}$. Above $1290 \mathrm{~cm}$ it becomes very organic but then changes $(1290-1460 \mathrm{~cm})$ to a gray silt, mottled, red-brown.

$840-1130 \mathrm{~cm}$ : Peat and peaty silt with beds of gray (5Y4/1) silt. Largely bryophytic peat up to $930 \mathrm{~cm}$, mostly sedge peat above this, some woody stems, some willow leaf fragments. Peat exhibits a platey parting. Upper metre becomes very woody, Picea cones present. Upper contact is sharp.

$300-840 \mathrm{~cm}$ : Silt, dark gray (5Y4/1) to grayish dark brown (2.5Y3/ 2 ), interbedded with yellowish brown (10YR5/8) silt.

285-300 cm: Volcanic tephra (10YR8/1). Lower and upper $5 \mathrm{~cm}$ evenly bedded, approximately 45 laminae $2-3 \mathrm{~mm}$ thick. Middle $5 \mathrm{~cm}$ massive.
245-285 cm: Silty fine sand, gray (5Y5/1) to olive gray $(5 Y 5 / 2)$. Lower contact gradational. Bedding mostly indistinct, but well bedded over upper $10 \mathrm{~cm}$. Non-organic, between 255-267 cm abundant organic carbonate fragments, small gastropods and Chara stem fragments. Sharp contact with overlying unit.

$105-245 \mathrm{~cm}$ : Silty fine sand, gray brown $(2.5 \mathrm{Y} 5 / 2)$, interbedded with gray (5Y5.5/) silty fine sand. Beds average $2 \mathrm{~cm}$ thick, over lower $10 \mathrm{~cm}$ they are deformed and involutions occur at $138 \mathrm{~cm}$ and $168 \mathrm{~cm}$. Elsewhere bedding is horizontal. Fine grained organic matter found throughout. Allochthonous organic matter including twigs. Forms distinct bed at $208 \mathrm{~cm}$.

80-105 cm: Silt, light olive brown (2.5Y5/2), massive, looks like single depositional event.

0-80 $\mathrm{cm}$ : Silt and very fine sand, light olive brown (2.5Y5/4), interbedded over lower $300 \mathrm{~cm}$ with beds $1-2 \mathrm{~cm}$ thick of gray silt. Bedding disturbed and broken by cracks. Upper $50 \mathrm{~cm}$ olive gray (5Y $5 / 2)$, with highly involuted and distorted bedding. Detrital wood present.

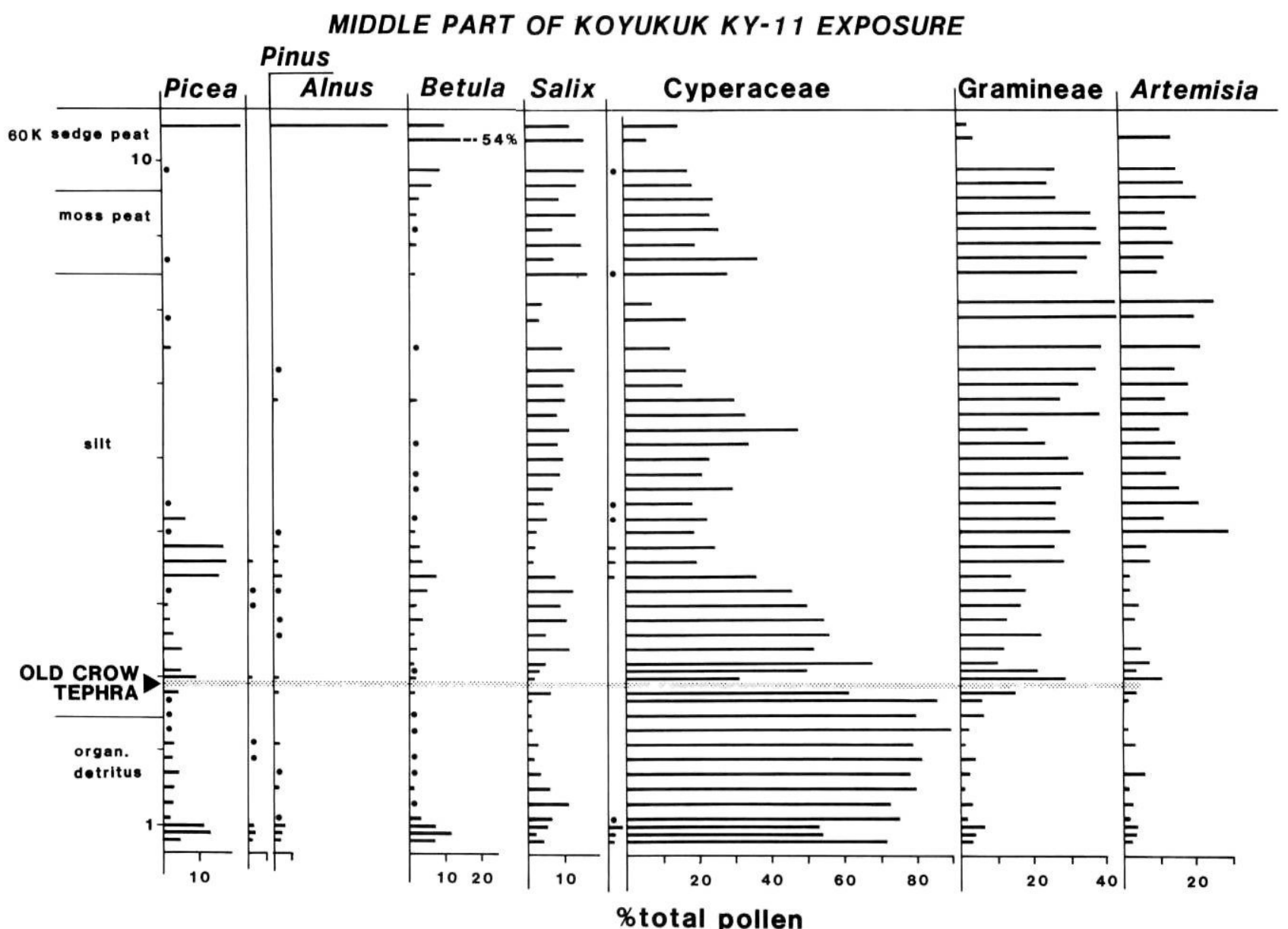

FIGURE 3. Partial pollen diagram from the Koyukuk K-11 exposure. Pollen spectra are from the middle part of the section, the stratigraphy of which is described in Table I. A complete pollen diagram for the KY-11 will be published at a later date. Note that the diagram includes only the main pollen types but percentages represent percent of total pollen.
Diagramme pollinique partiel de la coupe K-11 de Koyukuk. Le spectre pollinique provient de la partie centrale de la coupe stratigraphique décrite au tableau I. Le diagramme complet sera publié ultérieurement. Le diagramme ne comprend que les principaux types de pollen, mais les pourcentages comprennent l'ensemble du pollen. 
broad rise to a maximum of $8 \%$ between $380 \mathrm{~cm}$ and 460 $\mathrm{cm}$. Above $900 \mathrm{~cm}$ Betula values rise steadily, reaching $54 \%$ at $1030 \mathrm{~cm}$ but falling to $10 \%$ in the overlying woody peat. Salix percentages vary, with maxima of $16 \%$ at $850 \mathrm{~cm}$ and $1030 \mathrm{~cm}$. Most of the $\mathrm{KY}-11$ pollen record is dominated by non-arboreal (NAP) pollen, Cyperaceae (sedge) in particular. Between $80 \mathrm{~cm}$ and $270 \mathrm{~cm}$ sedge is very abundant, ranging from $53 \%$ to a maximum of $90 \%$. However, values drop off to less than $50 \%$ over the remainder of the section. Gramineae frequencies rise to $30 \%$ above the tephra and remain relatively high, peaking at $46 \%$ between $790 \mathrm{~cm}$ and $810 \mathrm{~cm}$.

Above the Old Crow tephra $(285-300 \mathrm{~cm})$ sandy shallow water sediments change to deeper water silts (Table I). Above the tephra the very high Cyperaceae percentages decline and those of algal colonies (Pediastrum and Botryococcus) rise (not shown in Fig. 3). Together these changes indicate a shallow lake or fen deepening near the time of Old Crow tephra deposition. In terms of regional vegetation, the combination of relatively high frequencies of Picea and Betula and a rise of Alnus above background suggest that boreal woodland (RITCHIE and LICHTI-FEDEROVICH, 1967; RITCHIE, 1976) characterized the site during times represented by the $75-100 \mathrm{~cm}$ and $440-480 \mathrm{~cm}$ intervals. The slight increase in Picea frequencies immediately above the level of the Old Crow tephra may also signify approaching treeline. Maximum values of Picea, Alnus, and Betula above $1030 \mathrm{~cm}$ clearly indicate a well developed boreal forest. This sample comes from near the base of a woody peat bed exposed over most of the exposure. Picea glauca cones and spruce logs are found throughout this unit providing further evidence of forest development. There is also an abundance of beaver chewed wood. In other parts of the section, especially over the intervals $350-440 \mathrm{~cm}$ and $520-1000 \mathrm{~cm}$, high values of Gramineae and Artemisia combined with the near absence of Picea, Betula, and Alnus call for open tundra vegetation.

In summary, the $10.5 \mathrm{~m}$ pollen record from the middle of the $\mathrm{KY}-11$ section reveals three probable times when open boreal forest existed at the site or spruce treeline stood nearby, and one phase when boreal forest was well developed locally. During the last one, Alnus percentages are higher than at any other time in the record and higher than in most modern pollen surface samples from boreal woodland regions (NELSON, 1979). This may signify warmer climatic conditions than at present. Separating the high spruce phases are episodes characterized by tundra-like spectra, including what must have been an extended period of severely cold and arid climate during the time represented by the $550-1000 \mathrm{~cm}$ interval.

The forest peat at the top of the section has been correlated with the woody peats from locations $\mathrm{KY}-10$ and $\mathrm{KY}-12$ (WESTGATE et al., 1983); therefore, the radiocarbon dates from those two sections suggest that the top of the KY-11 profile, as shown in Figure 3, is between 53000 and 59000 years in age. For the remainder of this report we use a rounded estimate of $60000 \mathrm{BP}$ for the peat, although admittedly, the finite radiocarbon dates from $\mathrm{KY}-10$ and $\mathrm{KY}-12$ may only represent minimum estimates (T. D. Hamilton. pers. comm., 1983), and the peat itself may represent 10000 or more years of time.

\section{FAIRBANKS REGION (ALASKA)}

The Fairbanks region of central Alaska contains a number of localities that expose one or more Late Pleistocene Tephras in stratigraphic context (Fig. 1) (PÉWÉ, 1975a, b).

Gold Hill Loess (Fig. 4) is the main unit in the basal part of many exposures. Although the sediments of this unit are perennially frozen, they are relatively inorganic compared to the silts of the overlying Eva Formation and Goldstream Formation (Fig. 4). Gold Hill loess is separated from these units by an angular unconformity (Fig. 4), representing a long period of thawing and slumping that occurred prior to 56900 years ago (Hv-1328) (PÉWÉ, 1975a). The Eva Formation, a woodrich silt that occurs immediately above the unconformity at the Eva Creek locality (PÉWÉ, 1975a; Fig. 6), may represent part of this warm interval. PÉWÉ (1975b) refers this interval of apparent warmer-than-present climate to the last (Sangamon) interglaciation, but we conclude that it represents an abnormally warm Wisconsinan interstadial (see below).

At most of the silt exposures in the Fairbanks area the Eva Formation is missing and Gold Hill Loess is capped by the Goldstream Formation, a fetid highly organic, perennially frozen silt unit with inactive (incompletely thawed) ice-wedges and abundant well preserved remains of vertebrates and plants (Fig. 4). PÉWÉ (1975b) has suggested that the Goldstream Formation is of Wisconsinan age. It probably includes several climatic oscillations (MATTHEWS, 1974b; SELLMANN, 1967); however, it appears never to have undergone a period of deep thawing like Gold Hill Loess. Thus, regional climate during Goldstream time was never much warmer than at present, and for much of that interval it was undoubtedly much colder, since treeline was often considerably lower than at present (MATTHEWS, 1968, 1970).

Old Crow tephra occurs within the Gold Hill Loess unit, hence stratigraphically below a radiocarbon date of $>56900$ BP (Fig. 4). At the nearby Halfway House exposure, Old Crow tephra is underlain by sediments containing a paleomagnetic excursion thought to represent the Blake Event (WESTGATE et al., 1985).

Scattered fossil insect and pollen evidence from the Gold Hill Loess shows that at least the upper part accumulated in a mesic tundra environment (MATTHEWS, 1968, 1970), but to date there is no paleoecological evidence from Fairbanks sediments that are directly associated with the tephra.

\section{BLUEFISH BASIN (NORTHERN YUKON)}

Old Crow tephra is known from several exposures in the Old Crow region of northern Yukon (Fig. 1). In the Bluefish Basin, one of several lowland areas drained by the Porcupine River and its tributaries, it occurs at the Twelvemile Bluff section (locality $\mathrm{HH} 228$ ), a $4 \mathrm{~km}$ long and $45 \mathrm{~m}$ high exposure on the Porcupine River downstream from the village of Old Crow. Twelvemile Bluff is the exposure discussed by HUGHES (1972) in his first iteration of the Pleistocene history of the region, and was also one of the sites (Porcupine 1) studied for pollen by LICHTI-FEDEROVICH (1974). The most recent examination of the site by the authors (1983) has helped to 
clarify the lateral extent of the tephra and the stratigraphy of the unit in which it occurs.

The complex stratigraphy of Twelvemile Bluff may be divided into six major units. Unit 4, which consists of alluvial silt, sand, and gravel in addition to fine-grained lacustrine sediments, is both underlain and overlain by lacustrine clays, Units 3 and 5 respectively (Fig. 5b). Old Crow tephra occurs inter-

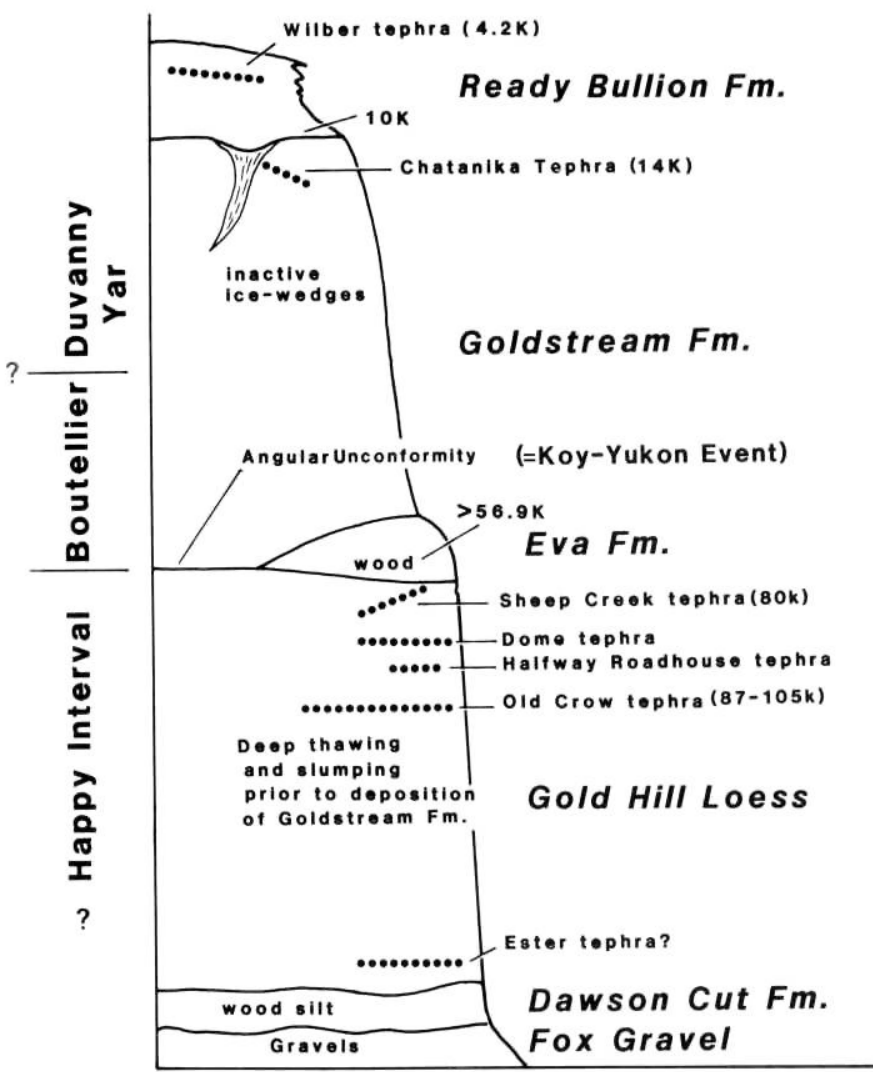

FIGURE 4. Generalized stratigraphy of frozen silt sections in the Fairbanks area (modified from PÉWE, 1975a). Sheep Creek tephra has not been found at same exposures as Old Crow tephra, but recent Uranium-series dates (HAMILTON and BISCHOFF, 1984) suggest that it is approximately 80,000 years in age, supporting its placement above Old Crow tephra in the diagram. Another unnamed tephra is known to occur below the Old Crow tephra and above Ester tephra (WESTGATE et al., 1982). Regional intervals on left margin are those established by HOPKINS (1982), but the interpretation shown there of the way in which they correlate with the Fairbanks stratigraphy differs slightly from that of Hopkins. The Koy-Yukon thermal event is defined in the text of this paper.

Stratigraphie généralisée de coupes de limon gelé dans la région de Fairbanks (modifié de PEWE, 1975a). Le tephra de Sheep Creek n'a pas été trouvé dans les mêmes coupes que celui de Old Crow, mais des datations à l'uranium récentes (HAMILTON et BISCHOFF, 1984) semblent indiquer que le tephra de Sheep Creek date de 80000 ans, ce qui justifie sa position au-dessus du tephra de Old Crow sur le diagramme. On sait aussi qu'un autre tephra s'est déposé entre le tephra de Old Crow et celui d'Ester (WESTGATE et al., 1982). Les intervalles qui apparaissent à gauche ont été établis par HOPKINS (1982), mais l'interprétation donnée ici quant à leur corrélation avec la stratigraphie de Fairbanks est quelque peu différente de celle de Hopkins. L'épisode de Koy-Yukon est expliqué dans le texte. mittently in the upstream and middle parts of the exposure within Unit $4 b$. The tephra is usually $4-6 \mathrm{~cm}$ in thickness but locally forms pods up to $20 \mathrm{~cm}$ thick. At some stations it is undulating, possibly due to post-depositional cryoturbation; whereas, elsewhere it is finely laminated and horizontally bedded.

The sediments from part of the Twelvemile Bluff section have been analyzed for their paleomagnetic signature (PEARCE et al., 1982). Additional paleomagnetic samples were collected in 1983 and preliminary study reveals a short $(40 \mathrm{~cm})$ interval of reversed polarity starting about $1.7 \mathrm{~m}$ below the tephra that is believed to be the Blake Event (WESTGATE et al., 1985).

A pollen study has been carried out at Twelvemile Bluff (LICHTI-FEDEROVICH, 1974), but at the time the samples were collected, the details of the stratigraphy of Unit 4 (Fig. 5b) were obscure. All but the upper three samples in Figure $5 \mathrm{a}$ come from the downstream end of the exposure (Fig. 5b). It is known that a channel cuts into unit $4 \mathrm{~b}$ in the middle part of the section, accounting for the absence of the tephra there, but it is not yet clear whether this channel also exists at the site where pollen samples were taken. In any case, the tephra has not been observed at the downstream part of the section, making uncertain any attempt to relate the pollen sequence to the tephra. What can be said with some certainty is that the upper part of Lichti-Federovich's pollen Zone C (Fig. 5a) probably postdates the tephra as does all of Pollen Zone D (Fig. 5a). In addition it is clear that the pronounced peak of spruce pollen in Zone D predates 37000 (GSC-2783) (Fig. 5b).

Unpublished pollen spectra (Lichti-Federovich, pers. comm., 1982) directly associated with Old Crow tephra come from the upstream part of the section (Table II). They show that the tephra was deposited in a shrub-birch tundra environment. Picea pollen frequencies decline from $11 \%, 39 \mathrm{~cm}$ below the tephra, to $4 \%, 3 \mathrm{~cm}$ below the tephra where Betula reaches a value of $42 \%$. Above the tephra Cyperaceae dominates $(45-50 \%)$ the pollen assemblages while Picea and Betula change only slightly.

Analyses of macrofossils by J.V.M. from immediately above and below the tephra show them to be dominated by seeds of aquatic plants yet they contain mostly fossils of terrestrial (rather than aquatic) insects. This discrepancy remains to be explained, but it is possible that the aquatic fossils are allochthonous, e.g., floated in during the early spring when shallow water covered the site, and that the insects and plants, such as willows (Salix wood occurs in the tephra: R. J. Mott, unpublished GSC wood identification report 84-18), represent a time later in the summer when the site had drained. Similar seasonal water level changes occur today in the Bluefish Basin.

Although Lichti-Federovich's pollen spectra above and below the tephra show significant percentages of Betula, birch macrofossils have not as yet been observed in samples directly associated with the tephra. This discrepancy probably reflects the fact that although birch shrubs (Betula glandulosa) are common in several widespread habitat types in the area today (RITCHIE and CWYNAR, 1976; RITCHIE, 1984) their distri- 
bution can often be patchy. The site from which the pollen samples come is $2 \mathrm{~km}$ from the spot where macrofossil samples were collected. The macrofossil assemblage from one sample contains a single spruce needle. This may be a rebedded "old" spruce fossil; however, spruce pollen percentages in the samples directly associated with the tephra are high enough to warrant the conclusion that a few spruce trees grew in the region at the time of the ash fall.

Two major horizons of ice-wedge pseudomorphs occur within Unit 4 (Fig. 5b). Both probably represent periods of regional thawing. The upper horizon is associated with a peat

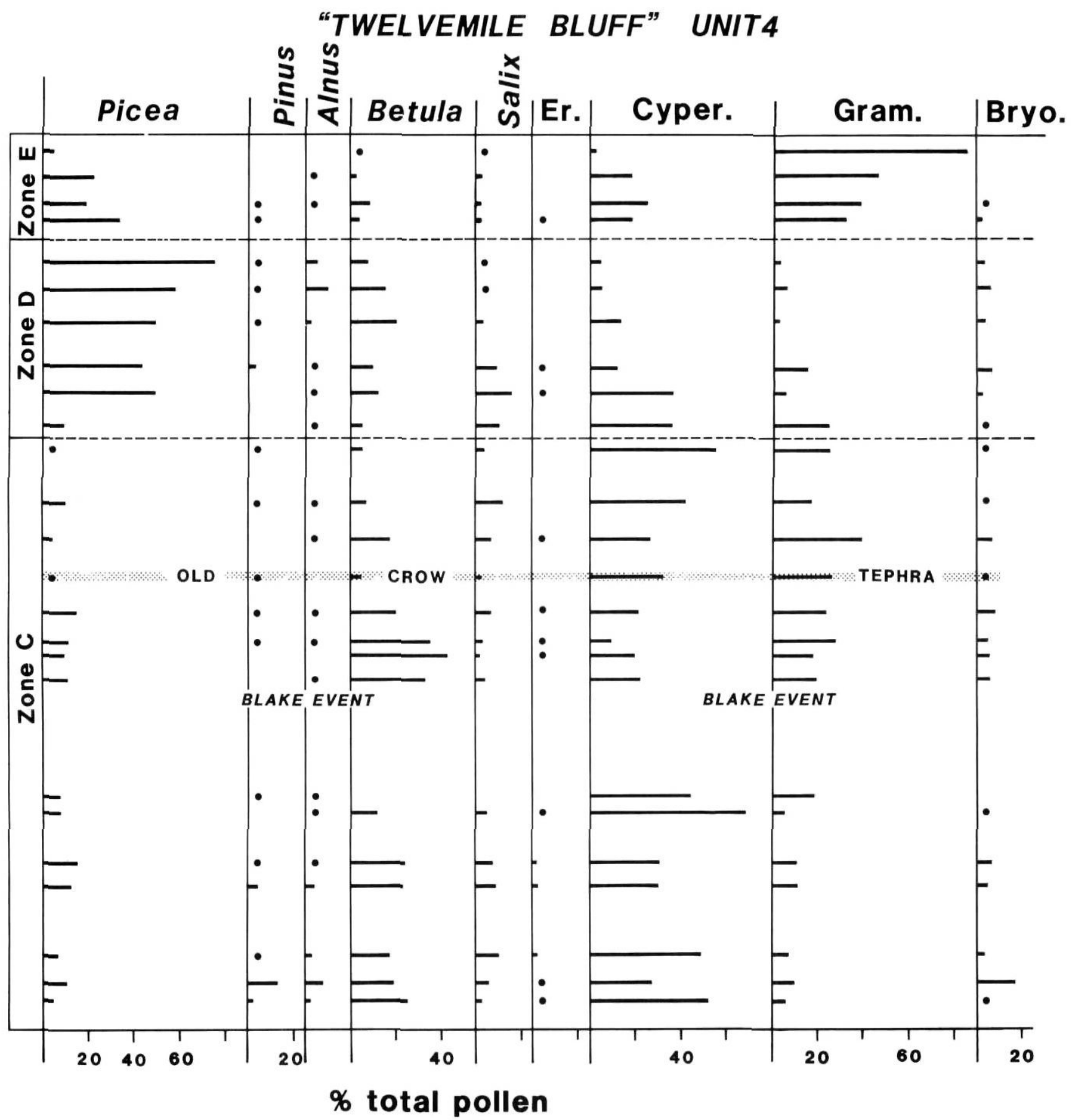

FIGURE 5a. Recast of pollen data from Unit 4 of the Twelvemile Bluff exposure (from LICHTI-FEDEROVICH, 1974 and unpublished data supplied from Lichti-Federovich). Zones are those used by LichtiFederovich. Er.: Ericaceae; Cyper.: Cyperaceae; Gram.: Gramineae; Bryo. : Bryophytes; Black circle: less than $2 \%$.
Refonte des données polliniques de l'unité $n^{\circ} 4$ de la coupe de la falaise de Twelvemile (de LICHTI-FEDEROVICH, 1974, et des donnees inédites du même auteur). La division zonale est celle de LichtiFederovich. Er.: Ericaceae; Cyper.: Cyperaceae; Gram.: Gramineae; Bryo.: Bryophytes; cercle noir: moins de $2 \%$. 
dated at $>37000 \mathrm{BP}$ (GSC-2783) which contains pollen and macrofossils indicative of forested conditions similar to the present (Table II). Old Crow tephra is intruded by the lower set of ice-wedge pseudomorphs. An exposure which illustrates this relationship is shown in Figure 5 of WESTGATE et al. (1983). The peat shown in that illustration is dated at $>53000$ BP (GSC-2676) and located a few tens of centimetres below the tephra. It has yielded pollen (Table II: "Ice-wedge peat") and a large assemblage of insect and plant macrofossils. Shrub birch macrofossils are abundant even though Betula accounts for only $6 \%$ of the pollen. Taken together the pollen and macrofossils from the peat call for a shrub-tundra environment.

Zone D of Lichti-Federovich's sequence is notable for its extremely high percentages of Picea (up to a maximum of $76 \%$ ) and as much as $11 \%$ Alnus. LICHTI-FEDEROVICH $(1973,1974)$, ruling out redeposition of spruce pollen, classified Zone D spectra as representing "Pollen Assemblage Type II", which is interpreted as a nonanalog "Forest-tundra type" vegetation. However, since spruce values within this zone are significantly higher than in modern surface samples (Table II), we believe Zone D represents boreal forest. The peak of spruce values probably coincides with the base of Unit 4c and may represent the same phase of climatic amelioration that caused thaw of the ice-wedges in Unit 4b.
In Zone E (Fig. 5a) Picea drops to less than $5 \%$ near the top of Unit 4 and the spectrum immediately beneath Unit 5 has a herb-tundra aspect. The climatic deterioration registered by the pollen samples from this zone reflects in a general way the climatic decline that ultimately culminated with deposition of glaciolacustrine clay of Unit 5 .

In summary, present information on the fossils and stratigraphy at Twelvemile Bluff indicate that Old Crow tephra was deposited in a shrub-tundra environment. Since the region is partly forested today, a colder climate than at present is implied. At least two periods of regional permafrost degradation, took place in the interval between deposition of the Old Crow tephra and $37000 \mathrm{BP}$. During one of these (probably coinciding with development of the lower pseudomorph horizon), boreal forest existed in a region that is only open forest today. Macrofossils of plants and insects that now have northern limits well south of Bluefish Basin (J. V. Matthews, Jr., unpublished GSC Fossil Arthropod Report 84 - 36 and Plant Macrofossil Report $84-36$ ) imply summer climate that was warmer than at present during initial deposition of Unit 4c.

\section{OLD CROW BASIN (NORTHERN YUKON)}

Old Crow Basin, is located immediately north of Bluefish Basin. Here Old Crow tephra occurs at several exposures along the Old Crow River (Fig. 1) where it is typically found

\section{TWELVEMILE BLUFF}

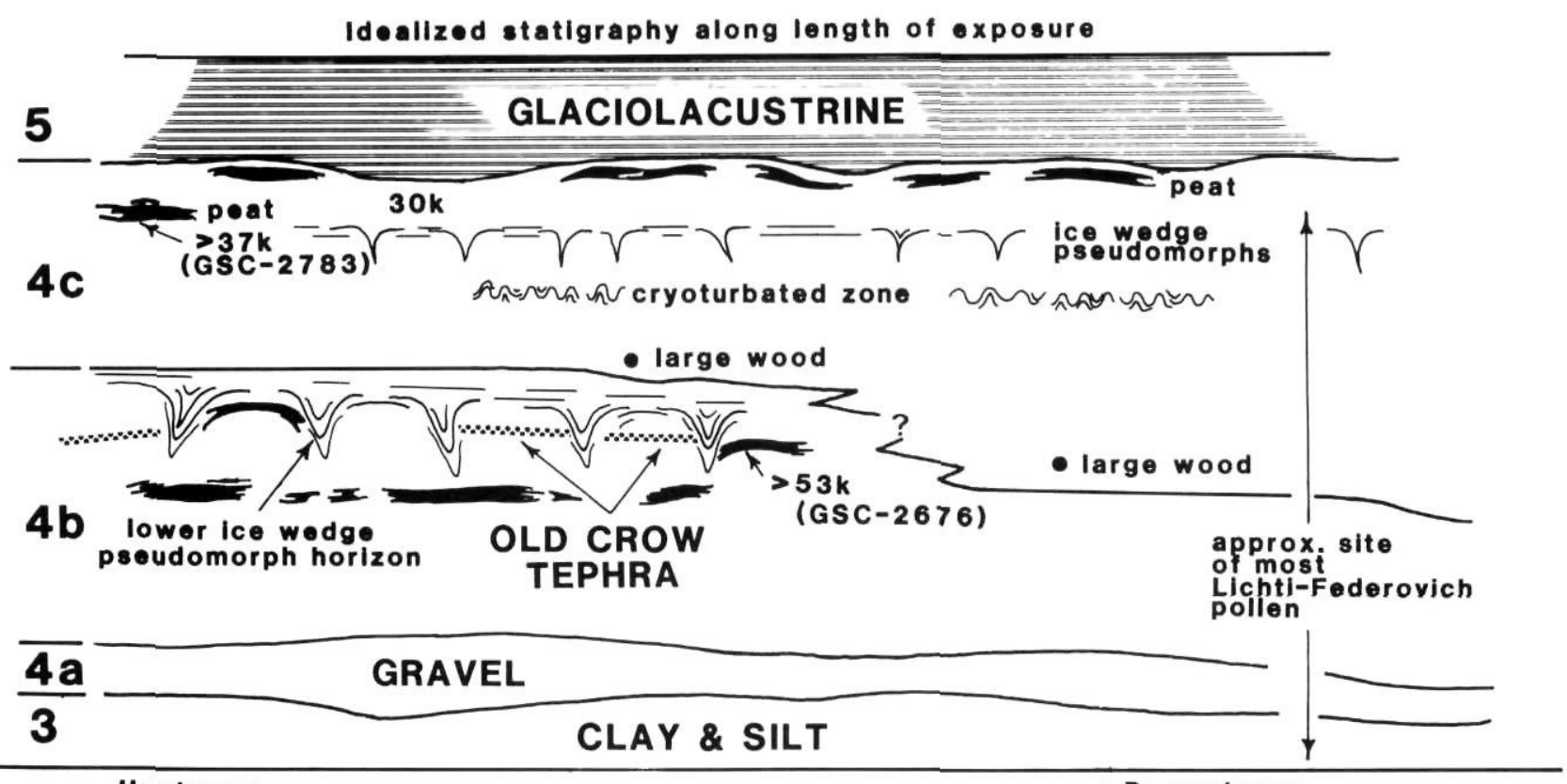

Upstream

FIGURE 5b. Stratigraphy and the approximate position of pollen sample series in relation to Old Crow tephra. Note that the part of Unit 4 containing the tephra is not present in the downstream part of the section. It has either been removed prior to deposition, or the lower part of $4 \mathrm{C}$ may be a downstream facies of upper $4 \mathrm{~b}$. See Table II for pollen samples directly associated with tephra and pollen data on Peat dated by GSC-2783.
Stratigraphie de la falaise de Twelvemile et localisation approximative du lieu d'échantillonnage de la série pollinique donnée en relation avec celle du tephra de Old Crow. La partie de l'unité n $n^{\circ}$ où se situe le tephra n'apparaît pas dans la portion aval de la coupe. Cette partie a été éliminée avant le dépôt de l'unité $n^{\circ} 4$, ou alors elle constituait un faciès aval de la partie supérieur de l'unité $n^{\circ} 4 \mathrm{~b}$. Voir le tableau II pour connaître les échantillons de pollen directement associés au tephra et les données polliniques de la tourbe datée (GSC-2783). 
TABLE ॥

Miscellaneous Twelvemile Bluff pollen samples and surface samples

\begin{tabular}{|c|c|c|c|c|c|c|c|c|c|c|c|}
\hline \multirow[b]{2}{*}{ Taxon } & \multicolumn{4}{|c|}{$\begin{array}{l}\text { Samples directly associated } \\
\text { with Old Crow tephra }\end{array}$} & \multirow[t]{2}{*}{$\begin{array}{c}\text { Ice- } \\
\text { wedge } \\
\text { peat }\end{array}$} & \multirow[t]{2}{*}{ Peat 3} & \multicolumn{5}{|c|}{$\begin{array}{l}\text { Modern surface samples } \\
\text { Old Crow Region }\end{array}$} \\
\hline & +64 & +12 & -3 & -39 & & & 1 & 2 & 3 & 4 & 5 \\
\hline Picea & 7.9 & 6.7 & 4.0 & 10.7 & $\ldots$ & 32.0 & 23.7 & 23.9 & 14.3 & 2.9 & 20.6 \\
\hline Pinus & 1.2 & 1.2 & $\ldots$ & 0.4 & $\ldots$ & 0.2 & 0.2 & $\ldots$ & $\ldots$ & $\ldots$ & $\ldots$ \\
\hline Alnus & 0.8 & $\ldots$ & 0.9 & $\ldots$ & 0.2 & 7.7 & 26.7 & 10.7 & 32.8 & 20.8 & 20.6 \\
\hline Betula & 3.7 & 6.7 & 42.2 & 39.8 & 6.1 & 12.7 & 31.3 & 35.7 & 34.8 & 57.0 & 22.0 \\
\hline Salix & 3.3 & 11.1 & 8.3 & 8.0 & 2.3 & 4.6 & 0.9 & 3.1 & 2.4 & 2.9 & 12.4 \\
\hline Populus & $\ldots$ & $\ldots$ & $\ldots$ & $\ldots$ & $\ldots$ & 0.6 & 0.4 & $\ldots$ & 1.1 & $\ldots$ & $\ldots$ \\
\hline Juniperus & $\ldots$ & $\ldots$ & $\ldots$ & $\ldots$ & $\ldots$ & $\ldots$ & $\ldots$ & $\ldots$ & 0.4 & $\ldots$ & 1.8 \\
\hline Abies & $\ldots$ & $\ldots$ & 0.9 & $\ldots$ & $\ldots$ & $\ldots$ & $\ldots$ & $\ldots$ & $\ldots$ & $\ldots$ & $\ldots$ \\
\hline Quercus & $\ldots$ & 0.4 & $\ldots$ & $\ldots$ & $\ldots$ & $\ldots$ & $\ldots$ & $\ldots$ & $\ldots$ & $\ldots$ & $\ldots$ \\
\hline Larix & $\ldots$ & $\ldots$ & $\ldots$ & $\ldots$ & $\ldots$ & 0.2 & $\ldots$ & $\ldots$ & $\ldots$ & $\ldots$ & $\ldots$ \\
\hline Cyperaceae & 45.0 & 50.2 & 11.8 & 17.2 & 77.4 & 27.6 & 2.3 & 15.0 & 2.4 & 10.5 & 22.0 \\
\hline Gramineae & 26.9 & 14.2 & 29.0 & 13.8 & 8.1 & 6.2 & 1.3 & 2.5 & 1.1 & 1.9 & 1.8 \\
\hline Ericaceae & 0.8 & 0.8 & 0.9 & 0.8 & $\ldots$. & 5.2 & 9.8 & 5.3 & 6.3 & 1.6 & 4.6 \\
\hline Artemisia & 1.2 & 0.4 & $\ldots$ & $\ldots$ & 0.2 & 0.2 & 0.4 & 1.1 & 2.4 & 1.3 & $\ldots$ \\
\hline Tubuliflorae & 2.9 & 1.2 & 0.9 & 2.7 & 2.1 & $\ldots$ & $\ldots$ & $\ldots$ & $\ldots$ & $\ldots$ & 0.5 \\
\hline Caryophyllaceae & 0.4 & 1.2 & 0.3 & $\ldots$ & 0.4 & $\ldots$ & $\ldots$ & 0.4 & $\ldots$ & $\ldots$ & $\ldots$ \\
\hline Rosaceae undif. & $\ldots$ & $\ldots$ & $\ldots$ & 3.4 & 0.4 & 1.0 & $\ldots$ & 0.9 & $\ldots$ & $\ldots$ & 0.9 \\
\hline Rubus chamaemorus & $\ldots$ & $\ldots$ & $\ldots$ & $\ldots$ & $\ldots$ & 1.0 & 3.0 & 0.7 & 1.4 & 0.3 & 0.5 \\
\hline Potentilla typ & $\ldots$ & $\ldots$ & $\ldots$ & $\ldots$ & $\ldots$ & 0.6 & $\ldots$ & 0.2 & $\ldots$ & 0.3 & 0.5 \\
\hline Chenopod.-Amaranthus & 0.4 & 2.8 & $\ldots$ & $\ldots$ & 2.1 & $\ldots$ & $\ldots$ & $\ldots$ & $\ldots$ & $\ldots$ & $\ldots$ \\
\hline Ranunculus typ & $\ldots$ & 0.4 & 0.6 & 1.5 & $\ldots$ & $\ldots$ & $\ldots$ & $\ldots$ & $\ldots$ & $\ldots$ & $\ldots$ \\
\hline Cruciferae & 1.2 & $\ldots$ & $\ldots$ & $\ldots$ & $\ldots$ & $\ldots$ & $\ldots$ & 0.2 & 0.7 & 0.7 & 1.4 \\
\hline Polemonium & $\ldots$ & $\ldots$ & $\ldots$ & 0.4 & 0.2 & $\ldots$ & $\ldots$ & $\ldots$ & $\ldots$ & $\ldots$ & $\ldots$ \\
\hline Phlox & 1.2 & 1.2 & $\ldots$ & $\ldots$ & 0.2 & $\ldots$ & $\ldots$ & $\ldots$ & $\ldots$ & $\ldots$ & $\ldots$ \\
\hline Thalictrum & $\ldots$ & 0.4 & 0.3 & $\ldots$ & $\ldots$ & $\ldots$ & $\ldots$ & $\ldots$ & $\ldots$ & $\ldots$ & $\ldots$ \\
\hline Liguliflorae & 1.2 & $\ldots$ & $\ldots$ & $\ldots$ & $\ldots$ & $\ldots$ & $\ldots$ & $\ldots$ & $\ldots$ & $\ldots$ & $\ldots$ \\
\hline Dryas & $\ldots$ & 0.8 & $\ldots$ & $\ldots$ & $\ldots$ & $\ldots$ & $\ldots$ & $\ldots$ & $\ldots$ & $\ldots$ & $\ldots$ \\
\hline Papaver & 0.8 & $\ldots$ & $\ldots$ & $\ldots$ & $\ldots$ & $\ldots$ & $\ldots$ & $\ldots$ & $\ldots$ & $\ldots$ & $\ldots$ \\
\hline Rubus typ. & 0.8 & $\ldots$ & $\ldots$ & $\ldots$ & $\ldots$ & $\ldots$ & $\ldots$ & $\ldots$ & $\ldots$ & $\ldots$ & $\ldots$ \\
\hline Saxifraga & $\ldots$ & $\ldots$ & $\ldots$ & 0.8 & $\ldots$ & $\ldots$ & $\ldots$ & $\ldots$ & $\ldots$ & $\ldots$ & $\ldots$ \\
\hline Ranunculaceae & $\ldots$ & $\ldots$ & $\ldots$ & $\ldots$ & $\ldots$ & $\ldots$ & $\ldots$ & $\ldots$ & $\ldots$ & 0.6 & $\ldots$ \\
\hline Umbelliferae & $\ldots$ & $\ldots$ & $\ldots$ & $\ldots$ & $\ldots$ & 0.6 & $\ldots$ & $\ldots$ & $\ldots$ & $\ldots$ & $\ldots$ \\
\hline Circaea & $\ldots$ & $\ldots$ & $\ldots$ & $\ldots$ & $\ldots$ & $\ldots$ & $\ldots$ & $\ldots$ & $\ldots$ & $\ldots$ & 0.5 \\
\hline Mitella typ. & $\ldots$ & $\ldots$ & $\ldots$ & $\ldots$ & $\ldots$ & $\ldots$ & $\ldots$ & $\ldots$ & $\ldots$ & $\ldots$ & 0.5 \\
\hline Penstemon typ. & $\ldots$ & $\ldots$ & $\ldots$ & $\ldots$ & $\ldots$ & $\ldots$ & $\cdots$ & $\ldots$ & $\cdots$ & $\cdots$ & 0.5 \\
\hline Shepherdia canadensis & $\ldots$ & $\ldots$ & $\ldots$ & $\ldots$ & $\ldots$ & $\ldots$ & $\ldots$ & $\ldots$ & $\ldots$ & $\ldots$ & 0.5 \\
\hline Valeriana & $\ldots$ & $\ldots$ & $\ldots$ & $\ldots$ & $\ldots$ & $\ldots$ & $\ldots$ & $\ldots$ & $\ldots$ & $\ldots$ & 0.5 \\
\hline Epilobium & $\ldots$ & $\ldots$ & $\ldots$ & 0.4 & $\ldots$ & $\ldots$ & $\ldots$ & $\ldots$ & $\ldots$ & $\ldots$ & $\ldots$ \\
\hline Gaura & $\ldots$ & 0.4 & $\ldots$ & $\ldots$ & $\ldots$ & $\ldots$ & $\ldots$ & $\ldots$ & $\ldots$ & $\ldots$ & $\ldots$ \\
\hline Myrica & $\ldots$ & $\ldots$ & $\ldots$ & $\ldots$ & $\ldots$ & $\ldots$ & $\ldots$ & 0.4 & $\cdots$ & $\ldots$ & $\ldots$ \\
\hline Myriophyllum & $\ldots$ & 0.4 & $\ldots$ & $\ldots$ & $\ldots$ & $\ldots$ & $\ldots$ & $\ldots$ & $\ldots$ & $\ldots$ & $\ldots$ \\
\hline Polyqonum bistorta typ & $\ldots$ & $\ldots$ & $\ldots$ & $\ldots$ & $\ldots$ & $\ldots$ & $\ldots$ & $\ldots$ & $\ldots$ & $\ldots$ & $\ldots$ \\
\hline Indeterminant pollen & $\ldots$ & $\ldots$ & $\ldots$ & $\ldots$ & 19.0 & 2.5 & 1.7 & 5.1 & $\ldots$ & 3.2 & 13.8 \\
\hline Unknown pollen & 0.8 & 0.4 & 0.3 & 1.1 & $\ldots$ & $\ldots$ & $\ldots$ & $\ldots$ & $\ldots$ & $\ldots$ & $\cdots$ \\
\hline ** POLLEN SUM ** & 242 & 253 & 348 & 261 & 479 & 518 & 460 & 448 & 287 & 313 & 218 \\
\hline Pteridophytes & 0.4 & 0.8 & 4.0 & 20.3 & $\ldots$ & $\ldots$. & $\ldots$ & $\ldots$ & $\ldots$ & $\ldots$ & $\ldots$ \\
\hline Lycopodium & $\ldots$ & 0.8 & $\ldots$ & 0.4 & $\ldots$ & 0.6 & 0.4 & 0.9 & $\ldots$ & $\ldots$ & $\ldots$ \\
\hline Isoetes & $\ldots$ & $\ldots$ & $\ldots$ & $\ldots$ & $\ldots$ & $\ldots$ & $\ldots$ & 0.4 & $\ldots$. & $\ldots$ & $\ldots$ \\
\hline Selaginella & $\ldots$ & $\ldots$ & $\ldots$ & $\ldots$ & $\ldots$ & $\ldots$ & $\ldots$ & $\ldots$ & $\ldots$ & $\ldots$ & 2.8 \\
\hline Equisetum & $\ldots$ & $\ldots$ & 0.3 & 0.4 & $\ldots$ & $\ldots$ & $\ldots$ & $\ldots$ & $\ldots$ & $\ldots$ & $\ldots$ \\
\hline Musci & 1.7 & 3.2 & 6.6 & 23.0 & 0.8 & 2.1 & 8.3 & 27.7 & 6.0 & 1.6 & 3.7 \\
\hline Old Palynomorphs & 0.8 & 0.4 & $\ldots$ & $\ldots$ & $\ldots$ & 0.4 & $\ldots$ & 10.7 & $\ldots$ & $\ldots$ & $\ldots$ \\
\hline
\end{tabular}

NOTES: Pollen assemblages associated with Old Crow Tephra come from Twelvemile Bluff, Porcupine River, Y.T. Peat $3=$ peat dated at $>37000$ BP (GSC-2783) (see Fig. 5b). Ice-Wedge Peat refers to peat shown in Fig. 5 of WESTGATE et al. (1983) and in Fig. 5b ( $>53000$ BP; GSC-2676) of this paper. Modern surface samples from Old Crow Basin: (1) Moss polster near unnamed lake ("Square Lake"); (2) Center of "Square Lake"; (3) Moss polster from tundra site at location CRH-32; (4) Small pond at location CRH-44; (5) Moss polster near last spruce stand on Timber Creek on north side of Old Crow Basin. All numbers = percent of total pollen. 
in cryoturbated clayey silts within the upper part of a thick alluvial unit bounded above and below by units of lacustrine clay. The age of the lower clay unit is unknown but is at least as old as early Wisconsinan, i.e. marine isotope Stage 5. The upper clay is the equivalent of Unit 5 at Twelvemile Bluff; hence, it began to accumulate in a meltwater lake between 25000 and 30000 years ago (MORLAN, 1985). Where Old Crow tephra occurs, it is usually located 5-7 m below the lower contact of the upper glaciolacustrine clay unit. At some sites it is intruded by (and slumped into) ice-wedge pseudomorphs that probably represent a subsequent period of regional warming. Because ice wedges are currently forming in the region, the degree of climatic amelioration represented by the pseudomorphs seems to be greater than today.

LICHTI-FEDEROVICH (1973) studied pollen samples from several of the Old Crow exposures where tephra has subsequently been found, but comparison of the unpublished stratigraphic notes associated with her collections shows that none of her samples include the upper part of the unit in which the tephra occurs. Thus at present there is little available pollen data that apply directly to the tephra. However, stratigraphic evidence does show that the tephra fell at a time when climate was cold enough for the formation of ice wedges (i.e., a permafrost environment as cold as the present), and we can also say with relative certainty that tephra deposition was followed sometime prior to $41100 \pm 1650$ BP (GSC2574) (BLAKE, 1984) by at least one period when climate was as warm or warmer than at present.

\section{CENTRAL AND SOUTHERN YUKON}

Two Old Crow tephra localities are found in central and southern Yukon. One of these is located in the upper Ogilvie River drainage (Fig. 1) where small wisps of the tephra occur in a terrace sequence stratigraphically above sediments containing an inactive (incompletely thawed) ice wedge (V. N. Rampton, pers. comm., 1982). Two other sites are located near Kluane Lake and the Alaska-Yukon border (WESTGATE, 1982) (Fig. 1). Although neither of these has yielded paleoecological information, they show conclusively that the Mirror Creek Glaciation (RAMPTON, 1971) in that region predates deposition of Old Crow tephra. The Mirror Creek Glaciation and its central Yukon equivalent, the Reid Glaciation, are generally considered to be no younger than Early Wisconsinan.

In summary the Old Crow tephra occurs within Imuruk Lake pollen zone G4, Ky-11 interval $285-300 \mathrm{~cm}$, the Gold Hill Loess of Fairbanks, Unit 3 of Old Crow Basin, and pollen zone $\mathrm{C}$ and Unit $4 \mathrm{~b}$ of the Twelvemile Bluff locality (Fig. 6). The Blake paleomagnetic reversal occurs below the tephra at Imuruk Lake and Twelvemile Bluff while evidence of a paleoclimate warmer than at present occurs above the tephra at all study localities.

\section{AGE OF THE OLD CROW TEPHRA}

The best previous estimate of the age of the Old Crow tephra is that it fell within the interval $60000-120000 \mathrm{BP}$ (WESTGATE et al. 1983). The minimum value comes from the fact that at the $\mathrm{KY}-11$ exposure in the Koyukuk valley the tephra occurs well below a level dated at 60000 BP. The higher value is derived from a fission-track date on the glass of the tephra (NAESER et al., 1982). Other estimates have appeared in the literature (e.g., 70000 and 80000 years in WESTGATE, 1982), but these appear to be no more than educated guesses.

Occurrence of Old Crow tephra in Imuruk core $\mathrm{V}$ offers the opportunity for derivation of a more objective and precise age estimate. In the core, the tephra occurs stratigraphically between a paleomagnetic reversal identified as the Blake Event (SHACKLETON, 1982) and a radiocarbon dated level (DIC-910, Fig. 7). Although, it has been suggested that the reversed zone in core $\mathrm{V}$ is a local anomaly (MARINO and ELWOOD, 1978), this now seems unlikely in view of the occurrence of a similar magnetic perturbation beneath Old Crow tephra at the Twelvemile Bluff exposure in the Yukon (see above). We follow SHACKLETON (1982) and assume that it represents the Blake Event, which is dated at between approximately 100000 and 125000 BP (SMITH and FOSTER, 1969). If a relatively constant mean deposition rate is assumed for core V, the two chronologic datum points (DIC-910 and the Blake Event) allow an extrapolated age estimate of 87000 105000 BP for Old Crow tephra (Fig. 7).

Independent confirmation for this estimate comes from comparison of pollen sequences. It is argued below that the top of the KY-11 section, dated at $60000 \mathrm{BP}$, correlates with the level of Imuruk Subzone $i_{1}$ where spruce values peak. If so, that level of Subzone $i_{1}$ is also 60000 in age. A line joining the point so defined with the mean value for DIC-910 falls within the stippled zone in Figure 7, and yields an estimate of about 100000 years for the age of the tephra.

Although the new estimate for the age of the tephra does not define the "instant" of the ash fall, it nearly halves the range of the former estimate. Most important it shows, as the previous fission-track based estimate does not, that the tephra was deposited during marine isotope Stage 5. Furthermore the tephra is almost certainly younger than isotope Stage $5 e$, which is generally accepted to represent the last interglacial, e.g., the last time when world ice volume was as low as at present, world sealevel as high or higher, and climate warmer (MANGERUD et al., 1979) (Fig. 8).

\section{ENVIRONMENT AT THE TIME OF THE OLD CROW TEPHRA}

Old Crow tephra is found at the base of Imuruk Lake Subzone $\mathrm{G}_{4}$, a period of slightly higher Picea, Alnus, and Betula values (11\%, $11 \%$, and $18 \%$, respectively). Surface samples from Imuruk Lake (COLINVAUX, 1964; COLBAUGH, 1968; SHACKLETON, 1982) show similar amounts of Picea pollen although distinctly higher values of Alnus and Betula. On the other hand, Subzone $\mathrm{G}_{4}$ values of Gramineae (20$30 \%$ ) and Artemisia (10-20\%) are considerably higher than in the modern pollen rain. Birch-dominated shrub tundra is the probable vegetation at Imuruk Lake during deposition of the tephra, but this tundra was probably more xeric than that of the present. Although spruce treeline may have been closer 


\section{THE LAST GLACIATION AND CLIMATE IN ALASKA-YUKON}

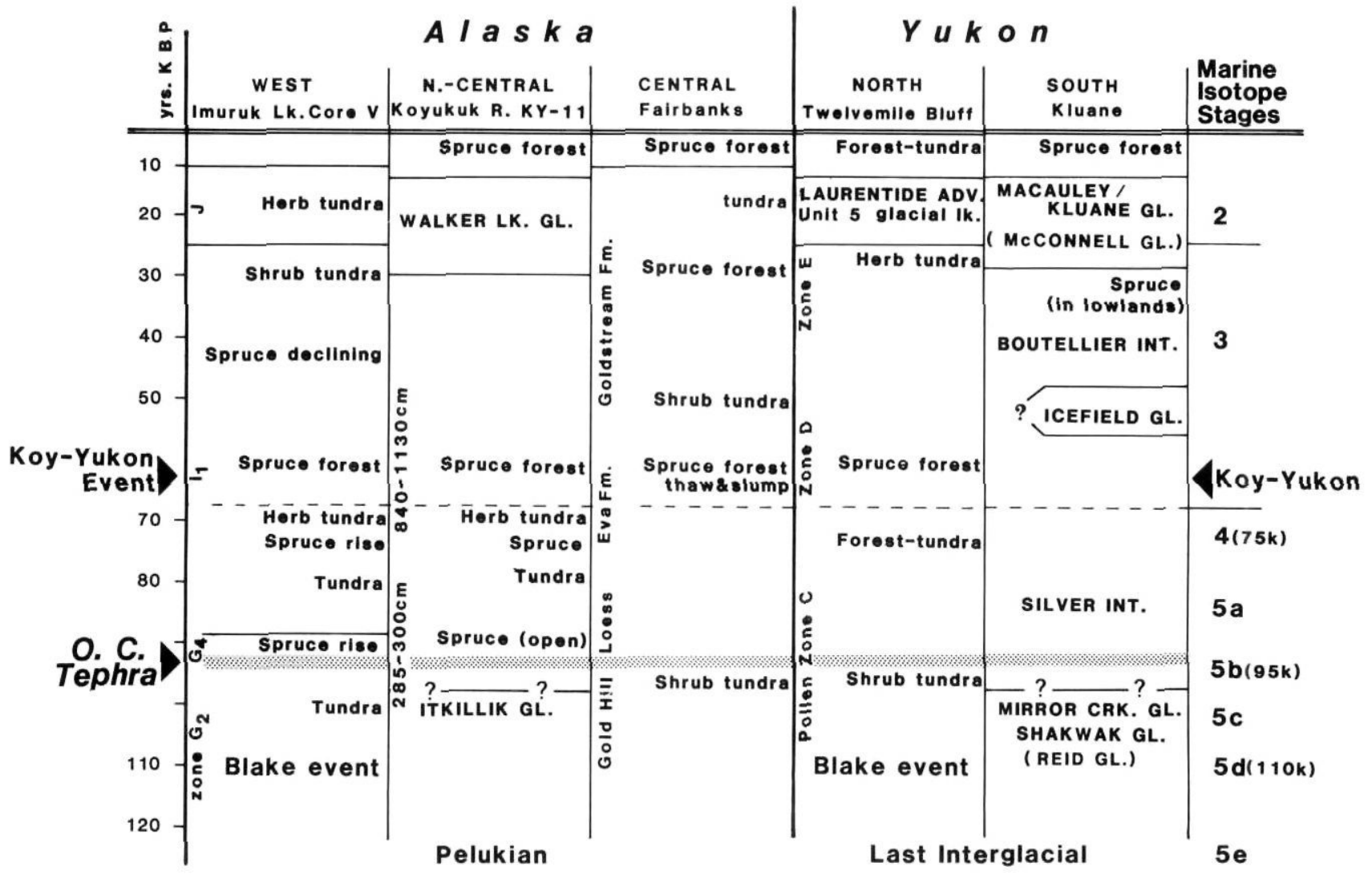

FIGURE 6. Summary diagram of events, zones and units associated with the Old Crow tephra and Koy-Yukon thermal event cited in text. For greater detail consult the appropriate section of text.
Diagramme abrégé comprenant les différents phénomènes, les zones et les unités associés au tephra de Old Crow et à l'épisode de KoyYukon dont on parle dans le texte.

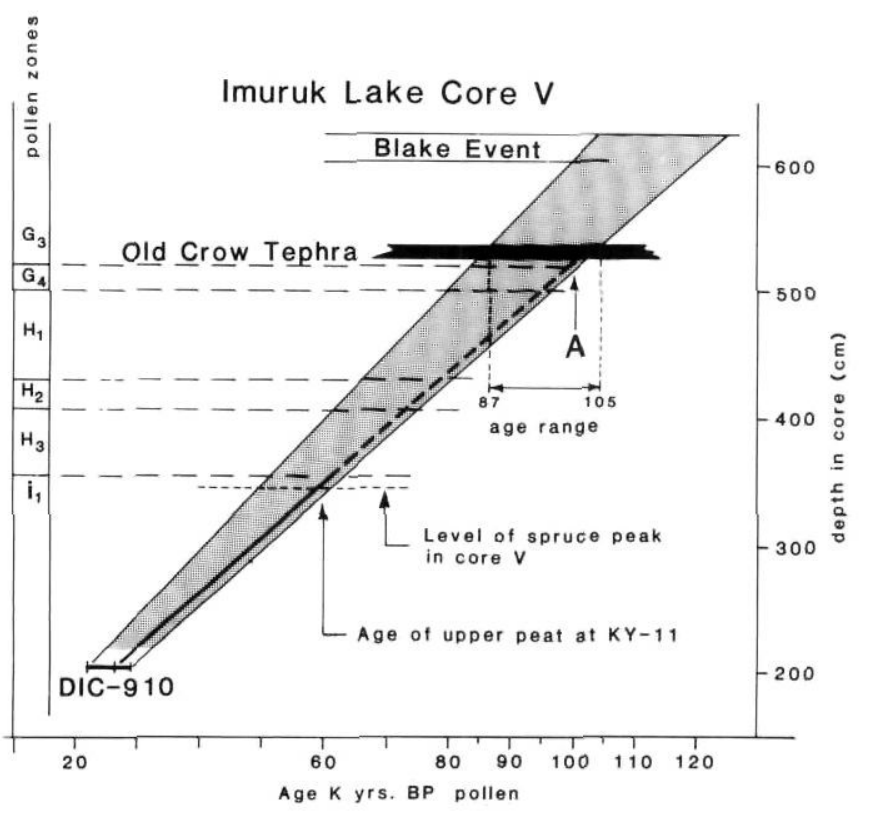

FIGURE 7. Extrapolated age of the Old Crow Tephra (based on data presented in SHACKLETON, 1982). Stippled band is the sedimentation rate derived using the max-min. age range for DIC-910 and the Blake Paleomagnetic Event and assuming constant average sedimentation rate between these two levels. Pollen zones are those of Imuruk Core V. Since the deposition of the tephra is an instantaneous event, the maximum and minimum estimates for its age coincide with the intersection of the field boundaries with the lowest occurrence of the tephra. Solid and dashed heavy line within the stippled field represents the extrapolated age (intersection A) for the tephra using DIC-910 and a $60000 \mathrm{yr}$ age for the spruce peak in Subzone i, (see text).

Extrapolation de l'âge du tephra de Old Crow (à partir des données de SHACKELTON, 1982). La zone en gris correspond au taux de sédimentation calculé à partir de l'écart maximal et minimal de la datation du niveau DIC-910 et de l'inversion magnétique de Blake, en supposant un taux de sédimentation constant entre les deux niveaux. Les zones polliniques sont celles du trou de forage Imuruk V. Le dépôt du tephra étant un événement instantané, l'estimation de son âge (minimal et maximal) doit correspondre avec l'intersection des limites de la zone en gris et de la base du tephra. La ligne continue qui se poursuit par un tireté gras dans la zone en gris correspond, à l'intersection A, à l'âge extrapolé pour le tephra à partir du niveau DIC-910 et la date de 60000 ans pour le maximum de l'épinette dans la sous-zone i, (voir le texte). 
to Imuruk Lake shortly after deposition of the tephra, at the "instant" of deposition it was probably further from the site than it is at present.

At Koyukuk locality KY-11 the tephra was also deposited during or just before an interval of slightly elevated Picea values. The local abundance of Cyperaceae and the lack of modern surface samples from lakes in interior Alaska hinders vegetation reconstruction. Nevertheless, it is likely, judging from surface samples at other boreal sites, that spruce percentages at the level of the tephra and immediately above it are lower than in the present Koyukuk Basin pollen rain. The tundra environment at $\mathrm{KY}-11$ at the time of the ash fall was probably also more xeric than is true of present lowland tundra in western Alaska.

In the Bluefish Basin at Twelvemile Bluff, Old Crow tephra was deposited at a time of low amounts (4\%) of Picea, and high frequencies of Cyperaceae, Gramineae, Salix, and Betula (Table II). Spruce percentages rise slightly $60 \mathrm{~cm}$ above the tephra. Macrofossils from an autochthonous peat positioned near the level of the tephra indicate a local environment of sedge-dominated wetlands interspersed with drier sites containing shrub-birch and willows. Modern surface samples from small ponds in the Old Crow Basin, $60 \mathrm{~km}$ north of Twelvemile Bluff, record 3-15\% Picea but, in contrast to the tephra-associated spectra, $20-30 \%$ Alnus and $20-60 \%$ Betula (Table II). It would appear then that in the Old Crow-Bluefish Basin area, Old Crow tephra was deposited in a xeric shrub tundra environment characterized by shrub-birch and willow, but with little or no Alnus. Spruce was rare to absent locally, but spruce treeline probably existed near-by, perhaps much closer than it was to Imuruk Lake and KY-11 on the Koyukuk River.

As paleoecological data become available from other Old Crow tephra exposures and those elsewhere is the Yukon, they will help to map the former regional position of treeline at the time of the tephra fall. Based on the evidence at hand, it is likely that at least open spruce forest existed somewhere in central and southern Alaska. While it is clear that the tephra was deposited when climate was colder than at present, the tephra nevertheless occurs inside the limit of the preceding glaciation. Thus, at the time of the tephra all glaciers in AlaskaYukon were on the wane (Fig. 6), and the subarctic biota probably in the initial stages of a northward movement.

\section{THE KOY-YUKON THERMAL EVENT}

The primary lacustrine pollen records from Koyukuk location KY-11 and Imuruk Lake core V can be correlated solely on the basis of their respective pollen sequences and their position with respect to Old Crow tephra (Fig. 6). Paleomagnetic studies at $\mathrm{KY}-11$ indicate normal field conditions through the entire $10 \mathrm{~m}$ of lacustrine silt (WESTGATE et al., 1983), showing that this record starts after the upper part of Imuruk Lake Subzone $G_{2}$ in which the Blake Event is registered. $\mathrm{KY}-11$ interval $75-125 \mathrm{~cm}$ shows a distinct Picea peak that is not as evident at Imuruk Lake. However, Subzone $\mathrm{G}_{3}$ and $\mathrm{KY}$ 11 interval $125-275 \mathrm{~cm}$ are both dominated by non-arboreal (NAP) pollen with little Picea or Alnus. Imuruk Subzone $\mathrm{G}_{4}$ is equivalent to the $230-320 \mathrm{~cm}$ interval at $\mathrm{KY}-11$ because both are bounded by Old Crow tephra. The sequence of fluctuations above the tephra is remarkably similar at both sites (compare Figs. 2 and 3). Zones $\mathrm{H}_{1}$ and $\mathrm{H}_{3}$ at Imuruk and the $350-425 \mathrm{~cm}$ and the $525-1030 \mathrm{~cm}$ intervals at $\mathrm{KY}$ 11 are characterized by high frequencies of Cyperaceae, Gramineae, and Artemisia, with rare or no Picea, Alnus, or Betula pollen. The pollen spectra imply herb-tundra and severely cold climate. Zone $\mathrm{H}$ at Imuruk and the $425-525 \mathrm{~cm}$ interval at KY-11 display higher values of Picea and Betula pollen, while pollen Subzone $\mathrm{i}$ and the $\mathrm{KY}-11$ woody peat above $1030 \mathrm{~cm}$ have maximum values of Picea and Betula in addition to high frequencies of Alnus. The last named taxon does not again become significant in east Beringian records until the Holocene. Thus both Imuruk core $\mathrm{V}$ and $\mathrm{KY}-11$ record three periods of warming following deposition of the Old Crow tephra.

The age of the lower one is fixed by our estimate for the age of the Old Crow tephra. The middle one (= Imuruk Subzone $\mathrm{H}_{2}$ ) appears to have occurred sometime between 62000 $80000 \mathrm{BP}$ (Fig. 7). This means that Subzone $\mathrm{H}_{2}$ and its presumed KY-11 equivalent (425-525 cm level) may represent a northwestern manifestation of the St. Pierre interstade of eastern Canada (dated at (72 700-77 400: QL-198, STUIVER et al., 1978, but see also OCCHIETTI, 1983, p. 11). The European Amersfort interstade (LUNDQVST and MOOK, 1981) is another possible equivalent of Imuruk Subzone $\mathrm{H}_{2}$.

The uppermost peak of spruce percentages (Subzone $i_{1}$ at Imuruk Lake and the top of the $\mathrm{KY}-11$ sequence) is presumed on the basis of radiocarbon dates to be approximately 60000 years in age. If so, it corresponds to the start of marine isotope Stage 3 (Fig. 8). But in the marine record Stage 3 does not portray warmer climate than at present. The Imuruk and $\mathrm{KY}$ 11 records do. One way to resolve this contradiction would be to reject previous correlation arguments and assign Imuruk Subzone $i_{1}$ to marine isotope Stage $5 a$. Stage $5 a$ in the marine record does represent a world climate more like that of the present than Stage 3 (Fig. 8). We reject this solution because: 1) it would mean that the close resemblance between the Imuruk and Koyukuk records is purely fortuitous; and 2) it would require that Zone $\mathrm{H}$ at imuruk have been deposited at the improbably high rate of $0.5 \mathrm{~m} / 1000$ years (assuming a median estimate of $93000 \mathrm{BP}$ for the age of Old Crow tephra). Thus it appears likely that isotope Stage 3 is the most likely correlative for Subzone $i_{1}$ and the upper peat at $\mathrm{KY}-11$.

The warming phase that occurred during Imuruk Subzone $\mathrm{i}_{1}$ and uppermost $\mathrm{KY}-11$ represents a significant Wisconsinan climatic event in east Beringia. Recognizing this, we here informally name it the "Koy-Yukon thermal event". An indication of its regional importance is that it is apparently represented at other sites in Alaska-Yukon (Fig. 6). For example, in the Fairbanks area it likely corresponds to the period of deep thawing that followed deposition of the Gold Hill Loess (Fig. 4). At Twelvemile Bluff in the Bluefish Basin of the Northern Yukon, the Koy-Yukon thermal event is probably portrayed by the lower ice-wedge pseudomorph horizon, the organic sediments at the base of Unit 4c, and the peak of spruce pollen in Lichti-Federovich's Zone D (Fig. 5a). At least one other period of deep thawing, accompanied by development 


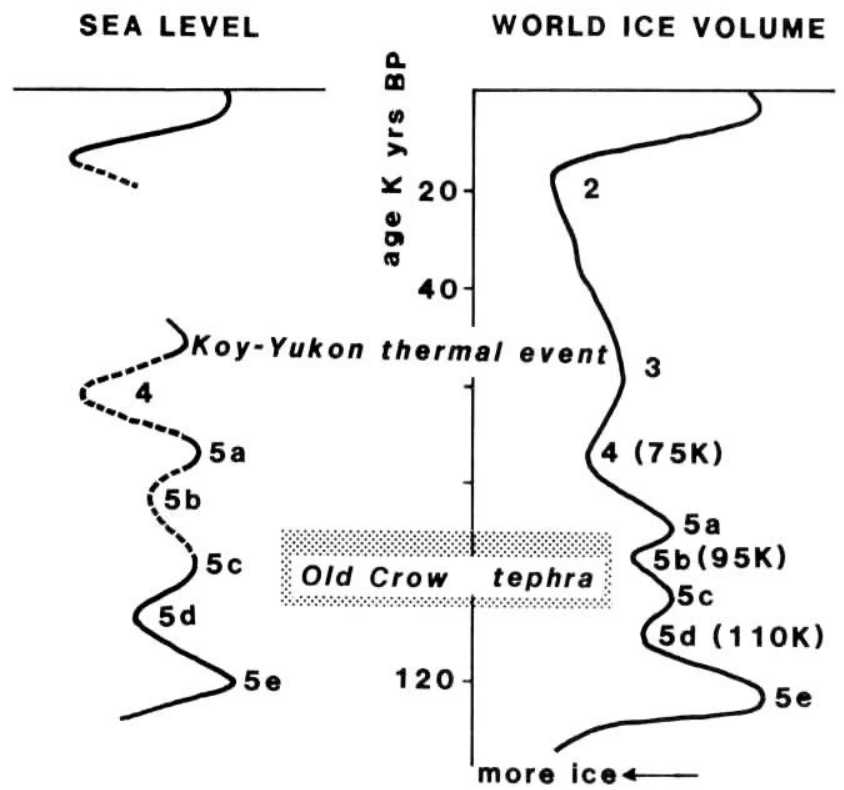

FIGURE 8. Comparison of marine isotopic stages (after DANSGAARD and DUPLESSY, 1981) with the extrapolated age for the Old Crow tephra and the Koy-Yukon thermal event. See text for discussion. The isotopic curve suggests that the last period of world climate as warm as at present occurred during isotope Stage $5 \mathrm{e}$, i.e., before deposition of Old Crow tephra.

Comparaison entre les phases isotopiques océaniques (selon DANSGAARD et DUPLESSY, 1981) et l'âge extrapolé du tephra de Old Crow et de l'épisode de Koy-Yukon (voir le texte). La courbe isotopique suggère que la dernière période pendant laquelle le climat était aussi doux que maintenant correspond à la phase isotopique $5 e$, c'est-à-dire avant le dépôt du tephra de Old Crow.

of boreal forest, occurred somewhat later but still prior to $37000 \mathrm{BP}$.

In the Old Crow Basin the Koy-Yukon thermal event may be represented by a period of regional thawing post dating the tephra and predating $41000 \mathrm{BP}$.

The Koy-Yukon thermal event probably lasted a minimum of several thousand years. If its start was approximately 60000 years, as concluded above, then it falls within the Boutellier Interval of HOPKINS (1982). As used here and by HOPKINS (1982); Fig. 2), the Boutellier Interval is different from DENTON and STUIVER's (1967) "Boutellier nonglacial interval". Hopkins' Boutellier Interval is the period of time between approximately 65000 BP (HOPKINS, 1982; Fig. 2) and the start of marine isotope Stage 2 at $25000 \mathrm{BP}$. The preceding Happy Interval (HOPKINS, 1982) is defined as including the Gold Hill Loess (Fairbanks), which we now know contains Old Crow tephra (WESTGATE et al., 1983) and the Blake Paleomagnetic Excursion (WESTGATE et al., 1985).

The Koy-Yukon thermal event is probably correlative with the earliest and warmest part of the Karginsk "interglacial" of eastern Siberia and the early Port Talbot Interstade of the North American mid-Continent (DREIMANIS and RAUKAS, 1975). ANDREWS and BARRY (1978) also record a period of significant warming (Quajon Interstade) at about 60000 BP on Baffin Island. The Fennoscandian ice sheet apparently retreated sharply at about the same time (BOULTON, 1979), corresponding to the Odderade of Brörup Interstadial (LUNDQVST and MOOK, 1981.

The outstanding characteristic of the Koy-Yukon thermal event is that it represents climatic conditions ordinarily associated with an interglacial (MATTHEWS, 1980; MATTHEWS and SCHWEGER, 1985; SCHWEGER and MATTHEWS, 1984). DREIMANIS and RAUKAS (1975) have shown that the early part of isotope Stage 3 had an interglacial character in several parts of the world, one of which was eastern Siberia. Our findings suggest that this was the case throughout the Beringian area. The anomalous interglacial signal of the KoyYukon thermal event probably results from the unique paleogeography of the region at that time. For example, there is probable cause for assuming that Middle Wisconsinan sea level was lower than at present (HOPKINS, 1982); and if it was as low as $-100 \mathrm{~m}$ (CRONIN, 1983), most of the Beringian land bridge would have been emergent. The climatic continentality implied by such a circumstance (BARRY, 1982) would have enhanced the effect of isotope Stage 3 climatic warming in east Beringia. The resulting warm, dry summers would have favored expansion of spruce (HOPKINS, 1959; BLACK and BLISS, 1980) and alder in western Alaska. Better drainage combined with warmer climate would also have promoted the occurrence of more closed boreal forest in the Old CrowBluefish basins, and may even have allowed spruce to expand onto the Yukon coastal plain. In this regard it is notable that aspen and cottonwood occurred on the Alaskan coastal plain around 52000 BP (HOPKINS et al., 1981).

Although floral records from Siberia and North America show that spruce did not cross the land bridge during the Koy-Yukon thermal event, it is possible that this was the time when some typical North American taiga plants (e.g., Populus balsamifera and Viburnum edule (high bush cranberry) (YURTSEV, 1982), gained a foothold in Chukotka, where they remain today as very rare elements of the Siberian flora. Similarly North American boreal mammals such as the red squirrel (Tamiasciurus hudsonicus) that are now extinct in Siberia may have moved into that area during the Koy-Yukon thermal event (AGADJANIAN, 1979).

Drought resulting from the continental influence of the emergent landbridge might have fostered the development of parkland or savanna-like environments in lowland areas of interior Alaska and the Yukon during the Koy-Yukon thermal event. This was probably the time when now disjunct or locally extinct Asian and North American steppe plants and animals such as Artemisia frigida and saiga antelope gained continuous distributions across Beringia (YURTSEV, 1982). Emerging evidence also suggests that the Middle Wisconsinan was the optimal time for development of the complex Mammoth-Steppe ungulate fauna recently discussed in detail by GUTHRIE (1982). It has been thought that this unique fauna, dominated by grazers was best developed during the Late Wisconsinan (isotope Stage 2) (MATTHEWS, 1982). Instead, the Late Wisconsinan may have been a time when the Mammoth-Steppe fauna had a precarious existence, perhaps even suffering the loss of some of its minor component taxa. 


\section{DISCUSSION}

Pollen and macrofossil data from three widely separated sites in east Beringia represent a west-east transect of paleoenvironmental conditions at the time of Old Crow Tephra deposition. The tephra fell during a period of climate colder and drier than at present, and was followed by a slight warming trend. Old Crow Tephra occurs at a number of sites in AlaskaYukon, and, according to its mapped distribution, will probably be found in cores from the Beaufort Sea, Bering Sea (WESTGATE, 1982), and possibly even in Chukotka. The tephra promises to broaden our knowledge of Middle Wisconsinan environments. It also allows us to define the Koy-Yukon thermal event, a period of abnormal warmth which we believe occurred approximately 60000 years ago at the start of the Boutellier interval and marine isotope Stage 3 (Fig. 8). The Koy-Yukon thermal event has all the characteristics of an interglacial. In fact sediments that we refer to it were formerly thought to be of Sangamon interglacial age (COLINVAUX, 1964; PÉWÉ, 1975b).

The occurrence of Old Crow Tephra in a number of stratigraphic contexts points up another intriguing aspect of the Wisconsinan climatic historic of Northwestern North America. In the southern Yukon the tephra overlies glacial drift that is presumed to be no younger than Early Wisconsinan (RAMPTON, 1971). In the Koyukuk region it is interstratified with drifts of the Early Wisconsinan Itkillik Glaciation (WESTGATE et al., 1983). The next major glaciation in Alaska-Yukon, including the intrusion of Laurentide ice in the eastern Yukon (HUGHES et al., 1981), dates to around 25000 BP (isotope Stage 2). If Old Crow tephra is as old as isotope Stage 5, then the Middle Wisconsinan non-glacial interval in AlaskaYukon was extraordinarily long. Furthermore, it includes episodes that on the basis of several lines of biotic evidence, appear to have been fully as cold as the preceding and following glacial periods. In Alaska-Yukon (east Beringia) marine isotope Stage 4 seems to have been characterized by little glacial activity; whereas, on a world scale, it was unquestionably a time of major ice build-up.

\section{ACKNOWLEDGEMENTS}

This work has benefited from the generous attitude of many colleagues who freely shared their data, results, and opinions. We want to give special thanks to John Westgate, Vern Rampton, Sigrid Lichti-Federovich, Paul Colinvaux, Owen Hughes, Thomas Hamilton, and Richard Morlan. The Quaternary Studies Program, University of Alaska, provided a stimulating opportunity for me (CES) to complete the pollen count of Koyukuk location II. And finally we must acknowledge our indebtedness to David Hopkins who has always encouraged us, by example and advice, to seek the "big picture". We also thank Dr. James C. Ritchie and Dr. Thomas H. Ager for their useful comments.

\section{REFERENCES}

AGADJANIAN, A. K. (1979): New data on the fossil mammalian fauna of Chukotka (abstract), XIV Pacific Science Congress, Section
B-III: Stratigraphy and Paleobiogeography of the Pacific Ring's Cenozoic, Abstracts of the Papers, Vol. 2, p. 164-166.

ANDREWS, J. T. and BARRY, G. (1978): Glacial inception and disintegration during the last glaciation, Annual Review of Earth Planet Sciences, Vol. 6, p. 205-228.

BARRY, R. (1982): Approaches to reconstructing the climate of the steppe-tundra biome, in D. M. Hopkins, J. V. Matthews Jr., C. E. Schweger, and S. B. Young, eds, Paleoecology of Beringia, Academic Press, p. 195-204.

BLACK, R. A. and BLISS, L. C. (1980); Reproductive ecology of Picea mariana (Mill.) BSP., at treeline near Inuvik, Northwest Territories, Canada, Ecological Monographs, Vol. 50, p. 331-354.

BLAKE, W., Jr. (1984): Geological Survey of Canada Radiocarbon Dates XXIV, Geological Survey of Canada Paper, 84-7, 35 p.

BOULTON, G. S. (1979): A model of Weichselian glacier variation in the North Atlantic region, Boreas, Vol. 8, p. 373-395.

COLGAUGH, P. R. (1968): The Environment of the Imuruk Lake Area, Seward Peninsula, Alaska, During Wisconsin Time, MSc. thesis, Ohio State University.

COLINVAUX, P. A. (1964): The environment of the Bering Land Bridge, Ecological Monographs, Vol. 34, p. 297-329.

CRONIN, T. M. (1983): Rapid sea level and climatic change: evidence from continental and island margins, Quaternary Science Reviews, Vol. 1, p. 177-214.

DANSGAARD, W. and DUPLESSY, J-C. (1981): The Eemian interglacial and its termination, Boreas, Vol. 10, p. 219-228.

DREIMANIS, A. and RAUKAS, A. (1975): Did middle Wisconsin, middle Weichselian, and their equivalents represent an interglacial or an interstadial complex in the Northern Hemisphere? in R. P. Suggate, and M. M. Cresswell, eds., Quaternary Studies, The Royal Society of New Zealand Bull., Vol. 13, p. 109-120.

GUTHRIE, R. D., (1982): Mammals of the Mammoth Steppe as paleoenvironmental indicators, in D. M. Hopkins, J. V. Matthews Jr., C. E. Schweger, and S. B. Young, eds. Paleoecology of Beringia, Academic Press, p. 307-326.

HAMILTON, T. D. (1982): A late Pleistocene glacial chronology for the southern Brooks Range: Stratigraphic Record and Regional Significance, Geological Society of America Bulletin, Vol. 93, p. $700-716$.

HAMILTON, T. D. and BISCHOFF, J. L. (1984): Uranium-Series dating of fossil bones from the Canyon Creek vertebrate locality in central Alaska, U. S. Geological Survey Circular, No. 939, p. 26-29.

HOPKINS, D. M. (1959): Some characteristics of the climate in forest and tundra regions in Alaska, Arctic, Vol. 12, p. 215-220.

(1982): Aspects of the paleogeography of Beringia during the late Pleistocene, in D. M. Hopkins, J. V. Matthews, Jr., C. E. Schweger, and S. B. Young, eds., Paleoecology of Beringia, Academic Press, p. 307-326.

HOPKINS, D. M., SMITH, P. A. and MATTHEWS, J. V., Jr. (1981) Dated wood from Alaska and the Yukon: Implications for forest refugia in Beringia, Quaternary Research, Vol. 15, p. 217-249.

HUGHES, O. L. 1972. Surficial geology of northern Yukon Territory and northwestern District of Mackenzie, Northwest Territories, Geological Survey of Canada Paper 69-36, $11 \mathrm{p}$.

HUGHES, O. L., HARINGTON, C. R., JANSSENS, J. A., MATTHEWS, J. V., Jr., MORLAN, R. E. RUTTER, N. W. and SCHWEGER, C. E. (1981): Upper Pleistocene stratigraphy, paleoecology, and archaeology of the northern Yukon interior, eastern Beringia, 1 Bonnet Plume Basin, Arctic, Vol. 34, p. 329-365.

LICHTI-FEDEROVICH, S. (1973): Palynology of six sections of late Quaternary sediments from the Old Crow River, Yukon Territory, Canadian Journal of Botany, Vol. 51, p. 553-564. 
(1974): Palynology of two sections of late Quaternary sediments from the Porcupine River, Yukon Territory, Geological Survey of Canada Paper 74-23, 6 p.

LUNDQQVIST, J. and MOOK, W. G. (1981): Finite date of the Jamtland interstadial, Boreas, Vol. 10, p. 133-135.

MARINO, R. J. and BROOKS, B. E. (1978): Anomalous magnetic fabric in sediments which record an apparent geomagnetic field excursion, Nature, Vol. 274, p. 581-582.

MANGERUD, J., SøNSTEGAARD, E. and SEJRUP, H. P. (1979): Correlation of the Eemian (interglacial) Stage and the deep-sea oxygen-isotope stratigraphy, Nature, Vol. 277, p. 189-192.

MATTHEWS, J. V., Jr. (1968): A paleoenvironmental analysis of three late Pleistocene coleopterus assemblages from Fairbanks, Alaska, Quaestiones Entomologicae, Vol. 4, p. 202-224.

- (1970): Quaternary environmental history of interior Alaska: pollen samples from organic colluvium and peats, Arctic and Alpine Research, Vol. 2, p. 241-251.

- (1974a): Quaternary environments at Cape Deceit (Seward Peninsula, Alaska) : evolution of a tundra ecosystem, Geological Society of America Bulletin, Vol. 85, p. 1353-1385.

(1974b): Wisconsin environment of interior Alaska: pollen and macrofossil analysis of a $27 \mathrm{~cm}$ core from Isabella Basin (Fairbanks, Alaska), Canadian Journal of Earth Sciences, Vol. 11, p. 812-841.

(1980): An early Wisconsinan warm interstadial in East Beringia? Abstract VI Biennial Meeting of AMQUA, Orono, Maine, p. 130-131.

- (1982): East Beringia during late Wisconsinan Time: a review of the biotic evidence, in D. M. Hopkins, J. V. Matthews, Jr. C. E. Schweger, and S. B. Young, eds., Paleoecology of Beringia, Academic Press, p. 127-150.

MATTHEWS, J. V., Jr. and SCHWEGER, C. E. (1985): Old Crow tephra: its significance for understanding the Early and Middle Wisconsinan climate history of East Beringia, in C. R. Harington, ed., Climatic Change in Canada 5, Syllogeus No. 55, p. 453-459.

MORLAN, R. E. (1980): Taphonomy and archaeology in the Upper Pleistocene of the northern Yukon Territory: a glimpse of the peopling of the New World, National Museum of Man, Mercury Series: Archaeological Survey of Canada Paper No. 94, 380 p.

(1985): Pleistocene Archaeology in Old Crow Basin: A Critical Reappraisal, in A. L. Bryan, ed., New Evidence for the Pleistocene Peopling of the Americas, Center for the Study of Early Man, University of Maine, Orono, p. 29-48.

MORLAN, R. E. and MATTHEWS, J. V., Jr. (1983): Taphonomy and paleoecology of fossil insect assemblages from Old Crow River (CRH-15) northern Yukon Territory, Canada, Géographie physique et Quaternaire, Vol. 37, p. 147-157.

NAESER, N. D., WESTGATE, J. A., and HUGHES, O. L. (1982): Fission-tract ages of late Cenozoic distal tephra beds in the Yukon Territory and Alaska, Canadian Journal of Earth Sciences, Vol. 19, p. 2167-2178.

NELSON, R. E. (1979) : Quaternary Environments of the Arctic Slope of Alaska, MSc. Thesis, University of Washington, $141 \mathrm{p}$.
OCCHIETTI, S. (1983): Laurentide ice sheet: oceanic and climatic implications, Palaeogeography, Palaeoclimatology, Palaeocology, Vol. 44, p. 1-22.

PEARCE, G. W., WESTGATE, J. A. and ROBERTSON, S. (1982): Magnetic reversal history of Pleistocene sediments at Old Crow, northwestern Yukon Territory, Canadian Journal of Earth Sciences, Vol. 19, p. 919-929.

PÉWÉ, T. L. (1975a): Quaternary stratigraphic nomenclature in unglaciated central Alaska, U.S. Geological Survey Prof. Paper 862, $32 \mathrm{p}$.

(1975b): Quaternary geology of Alaska, U.S. Geological Survey Professional Paper 835, $145 \mathrm{p}$.

RAMPTON, V. N. (1971): Late Pleistocene glaciations of the SnagKlutlan area, Yukon Territory, Arctic, Vol. 24, p. 277-300.

RITCHIE, J. C. (1984): Past and Present Vegetation of the Far Northwest of Canada, University of Toronto Press, Toronto.

RITCHIE, J. C., and L. C. CWYNAR (1976): Paleobotany Report, in Northern Yukon Research Programme, University of Toronto, 1976 Annual Report.

SCHWEGER, C. E. and MATTHEWS, J. V., Jr. (1984): Mid-Wisconsinan climatic history for Alaska-Yukon as revealed by Old Crow tephra, Abstract, VIII Biennal AMQUA Meeting, p. 113.

SELLMANN, P. V. (1967): Geology of the USA CRREL permafrost tunnel Fairbanks, Alaska, Cold Regions Research \& Engineering Laboratory, Technical Report 199, 22 p.

SHACKLETON, J. (1982): Environmental histories from Whitefish and Imuruk Lakes, Seward Peninsula, Alaska, Institute of Polar Studies Report No. 76., Ohio State University, 49 p.

SMITH, J. D. and FOSTER, J. H. (1969): Geomagnetic reversal in Brunhes Normal polarity epoch, Science, Vol. 163, p. 565-567.

STUIVER, M., HEUSSER, C. J. and YANG, I. C. (1978): North American glacial history extended to 75,000 years ago, Science, Vol. 200, p. 16-21.

WESTGATE, J.A. (1982): Discovery of a large-magnitude, late Pleistocene volcanic eruption in Alaska, Science, Vol. 218, 789790.

WEStGate, J. A., PÉWÉ, T. L. and GORTON, M. P. (1982): Tephrochronology of the Gold Hill Loess in central Alaska, Abstracts, The Geological Society of America 95th Annual Meeting, Louisiana, p. 645-646.

WESTGATE, J. A., HAMILTON, T. D., and GORTON, M. P. (1983): Old Crow Tephra: a new late Pleistocene stratigraphic marker across North-Central Alaska and Western Yukon Territory, Quaternary Research, Vol. 19, p. 38-54.

WESTGATE, J. A., WALTER, R. C., PEARCE, G. W. and GORTON, M. P. (1985): Distribution, stratigraphy, petrochemistry, and paleomagnetism of the late Pleistocene Old Crow tephra in Alaska and the Yukon, Canadian Journal of Earth Sciences, Vol. 22, p. 893-906.

YURTSEV, B. A. (1982): Relics of the xerophyte vegetation of Beringia in Northeastern Asia, in D. M. Hopkins, J. V. Matthews Jr., C. E. Schweger, and S. B. Young, eds., Paleoecology of Beringia, Academic Press, p. 157-177. 